Canadian Science Publishing

Canadian Journal of Earth Sciences Revue canadienne des sciences de la Terre

\title{
Using a Multiple Variogram Approach to Improve the Accuracy of Subsurface Geological Models
}

\begin{tabular}{|r|l|}
\hline Journal: & Canadian Journal of Earth Sciences \\
\hline Manuscript ID & cjes-2016-0112.R3 \\
\hline Manuscript Type: & Article \\
\hline Date Submitted by the Author: & 30 -Apr-2017 \\
\hline Complete List of Authors: & $\begin{array}{l}\text { MacCormack, Kelsey; Alberta Geological Survey, } \\
\text { Arnaud, Emmanuelle; University of Guelph, } \\
\text { Parker, Beth; University of Guelph, School of Engineering; University of } \\
\text { Guelph, G360 Institute for Groundwater Research }\end{array}$ \\
\hline $\begin{array}{r}\text { Is the invited manuscript for } \\
\text { consideration in a Special } \\
\text { Issue? : }\end{array}$ & Quaternary Geology of Southern Ontario and Applications to \\
\hline Keyword: & $\begin{array}{l}\text { Variogram, Three-dimensional, Quaternary Geology, Paris Moraine, } \\
\text { Geologic Model }\end{array}$ \\
\hline \multicolumn{2}{|c}{} \\
\hline
\end{tabular}


1 Using a Multiple Variogram Approach to Improve the Accuracy of 2 Subsurface Geological Models

9 Kelsey MacCormack ${ }^{1,3, *, 4}$, Emmanuelle Arnaud ${ }^{1,3}$, Beth L. Parker ${ }^{2,3}$

$10{ }^{1}$ School of Environmental Sciences, University of Guelph, Guelph, Ontario, N1G 2W1, Canada

$11{ }^{2}$ School of Engineering, University of Guelph, Guelph, Ontario, N1G 2W1, Canada

$12{ }^{3}$ G360 Institute for Groundwater Research, University of Guelph, 360 College Avenue, Guelph, Ontario 13 N1G 2W1, Canada

14

15 *Corresponding author: kelsey.maccormack@aer.ca; 1-780-644-5502

${ }^{4}$ Present Address: Alberta Geological Survey; Alberta Energy Regulator, 4999-98 Avenue, Edmonton AB, T6B 2X3 
ABSTRACT

Subsurface geological models are often used to visualize and analyze the nature, geometry, and variability of geologic and hydrogeologic units in the context of groundwater resource studies. The development of three-dimensional (3D) subsurface geological models covering increasingly larger model domains has steadily increased in recent years, in step with the rapid development of computing technology and software, and the increasing need to understand and manage groundwater resources at the regional scale. The models are then used by decision makers to guide activities and policies related to source water protection, well field development, and industrial or agricultural water use. It is important to ensure that the modelling techniques and procedures are able to accurately delineate and characterize the heterogeneity of the various geological environments included within the regional model domain. The purpose of this study is to examine if 3D stratigraphic models covering complex Quaternary deposits can be improved by splitting the regional model into multiple sub-models based on the degree of variability observed between surrounding data points and informed by expert geological knowledge of the geological/depositional framework. This is demonstrated using subsurface data from the Paris Moraine area near Guelph in southern Ontario. The variogram models produced for each submodel region were able to better characterize the data variability resulting in a more geologically realistic interpolation of the entire model domain as demonstrated by the comparison of the model output with pre-existing maps of surficial geology and bedrock topography as well as depositional models for these complex glacial environments. Importantly, comparison between model outputs reveal significant differences in the resulting subsurface stratigraphy, complexity and variability, which would in turn impact groundwater flow model predictions. 
INTRODUCTION

Many three-dimensional (3D) subsurface geological models were created for various regions in

41 Southern Ontario following the Walkerton Inquiry (O'Connor 2002) and the consequent source water

42 protection initiatives. Such models have been used in Ontario and elsewhere for a number of

43 environmental management applications including risk assessments of municipal or hazardous waste

44 and the management and protection of groundwater resources (e.g. Artimo et al. 2004; Bajc et al. 2011;

45 Thomason and Keefer 2011; Atkinson and Glombick 2015). In other cases, 3D geological models have

46 been used in the context of the delineation and remediation of contaminants, and the exploration and

47 extraction of aggregate and mineral resources (Houlding 2000; Kauffman and Martin 2008). The

48 overall aim of these models is to characterize the nature and distribution of subsurface materials, which

49 typically necessitate modelling near-surface glacial deposits, in order to constrain the modelling of the

50 groundwater flow system, contaminant migration pathways, transport rate of contaminants and risk to

51 receptors, or to optimize natural resource extraction (Wycisk et al. 2009; Babak et al. 2014; Dunkle et al.

52 2016). Accurately characterizing glacial deposits can be particularly difficult, as subsurface stratigraphy

53 in glacial settings typically have short length scales, abrupt facies transitions, and erosionally truncated

54 relationships as a result of the dynamic nature of these depositional environments and multiple and

55 spatially variable erosional and depositional events associated with repeated ice advances and retreats.

The scale of 3D subsurface geological models developed in the context of groundwater resource management have been rapidly increasing over the past decade to cover larger model domains (Bajc and

58 Newton 2005; Logan et al. 2005; Kessler et al 2007; Arihood 2008; Gunnink et al. 2013; McLaughlin et

59 al. 2015). With increasing size, regional models (100's of $\mathrm{km}^{2}$ or more) are likely to encompass a 60 variety of depositional environments resulting in multiple heterogeneous zones within a 
61 stratigraphic/hydrostratigraphic model (Weissmann et al. 1999; Babak et al. 2014; Dunkle et al. 2016).

62 Modelling heterogeneity across regional study areas can lead to erroneous interpretations when models

63 are constructed using geostatistical interpolators that attempt to incorporate this variability without

64 acknowledgment of these sub-domains (de Marsily et al. 2005).

65 The most commonly applied geostatistical interpolation algorithm is ordinary kriging (Kravchenko

66 and Bullock 1999; Johnston et al. 2001; Jones et al. 2003; Kravchenko 2003; Mueller et al. 2004).

67 Ordinary kriging is a distance weighted estimation algorithm that uses a variogram to characterize the

68 variability between individual data points across a study area to optimize the weights assigned to the

69 data points during the estimation of each grid node (Issaks and Srivastava 1989; Krajewski and Gibbs

70 1996). If there is a large amount of spatial variability within the dataset, it may not be possible to fit a

71 reliable variogram, which will result in poor estimates with large associated errors (Weber and Englund

72 1994; Gringarten and Deutsch 2001). The problem with interpolating subsurface units across regional

73 models containing zones of both high and low variability (the current standard procedure), is that the

74 resulting variogram must characterize the variability within the entire model area, and as a result,

75 produces a blended estimate with unknown bias of the actual variability (Houlding 2000). This problem

76 is compounded by the fact that geostatistical interpolators are often utilized as a 'black box' tool by

77 users who do not fully understand how the predictions were calculated or if they are realistic in their

78 geologic context. Together, these factors may severely compromise the accuracy of the model outputs

79 (Goodchild and Haining 2004). Unfortunately, little attention (if any at all) is paid to variogram analysis,

80 which lies at the center of all geostatistical analysis and estimation for assessing how similar the existing

81 and interpolated data are to one another (Gringarten and Deutsch 2001; Chiles and Delfiner 2012). 
82 The objective of this study is to determine if a model can be improved by splitting the regional

83 model into multiple sub-models based on the degree of variability observed between surrounding data

84 points and our understanding of the depositional environment. This modelling approach will aim to

85 incorporate the existing geologic framework ('hard' data, eg. topography, geomorphic features, geologic

86 logs) with 'soft' qualitative data (e.g. geological knowledge of specific depositional environments) to

87 define the sub-model domains, thus optimizing the measured data values as input to the geostatistical

88 model. The hypothesis is that by separating the regional model domain into sub-models based on the

89 data variability and our understanding of the geologic context, a variogram can be produced for each

90 sub-model region that is more representative of the true variability within the data for each area, thus

91 resulting in a more geologically realistic interpolation and model results for both the sub-domains and

92 entire model domain (Weissmann et al. 1999; de Marsily et al. 2005).

93 The regional model domain for this study encompasses a $165 \mathrm{~km}^{2}$ area that includes a section of the

94 Paris Moraine near Guelph, Ontario (Figure 1). This was an ideal dataset to use for this study because

95 the model area contains several geological environments and has been identified by the province of

96 Ontario as an area requiring a water budget evaluation and development of a source water protection

97 policy (Ontario Ministry of the Environment 2009). Developing methods to more accurately delineate

98 the form and geometry of the subsurface sedimentary deposits as presented here can be used to help

99 quantify the impact of the Paris Moraine on groundwater recharge and flow variability as well as inform

100 our understanding of potential contaminant pathways and receptors-both important aspects of current

101 water resource management in the region (Russell et al. 2009; Ontario Ministry of the Environment

102 2009). The method developed here can also be used elsewhere, in other glaciated regions where a 
103 variety of depositional environments are expected to create significant heterogeneity across a modeling 104 domain.

105

106

107

108

109

110

\section{BACKGROUND GEOLOGY}

The Guelph area was glaciated multiple times during the Quaternary period resulting in a complex interfingering of glacial deposits overlying Paleozoic bedrock and multiple glacial landforms at surface (Karrow 1963, 1968, 1987; Chapman and Putnam 1984; Barnett 1992). Drift thickness over bedrock ranges from 10-15 $\mathrm{m}$ in the outwash and till plains and up to $40 \mathrm{~m}$ along the Paris Moraine. The oldest glacial deposits in the region are defined as Early to Mid-Wisconsinan in age and are either till (Canning Till) or stratified sediments, though these are only documented in a few places. Overlying these older deposits is a relatively continuous regional basal till (Catfish Creek Till) deposited during the major ice advance of the Nissouri Phase (Late Wisconsinan; Table 1) has been described by Karrow (1968, 1987). The Catfish Creek Till unit is overlain by kame and outwash deposits of the subsequent Erie glacial retreat phase. The Port Stanley Till is found at surface in the NW section of the study area and is thought to be associated with the younger Port Bruce ice advance, whereas the Wentworth Till at surface in the SE sector records an ice readvance during the overall retreat of the Erie-Ontario lobe (Mackinaw Phase) (Table 1; Karrow 1987; Barnett 1992; Karrow et al. 2000). In some areas, Karrow (1968, 1987) described an additional till between the Catfish Creek Till and the tills at surface, which he interpreted as Port Bruce in age (Maryhill/Middle Till), although the similarities between Maryhill and Port Stanley Tills in this area, and the limited stratigraphic control and radiometric data do not always allow differentiation of tills at depth. Lastly, laterally discontinuous kame and outwash deposits occur at surface throughout the study area and record glaciofluvial processes associated with ice retreat from the region. 
The most prominent landform at surface is the Paris Moraine, a NE-SW trending topographic

126 high that cuts across the study area (Sadura et al. 2006) and records stagnation or minor readvance

127 during the Mackinaw Phase (Karrow 1968). It is defined by a core belt of hummocky topography and is 128 composed of silty sandy diamict (Wentworth Till), as well as coarse-grained outwash, kame and ablation 129 deposits. The surrounding landscape consists primarily of outwash plains on either side of the moraine, 130 as well as a drumlinized till plain with Port Stanley Till at surface on its NW side (Karrow 1968; 131 Chapman and Putnam 1984). The Paris Moraine is thought to be an important hydrogeologic feature for 132 enhanced recharge to the underlying bedrock aquifer and provides spatially distributed baseflow to 133 adjacent creeks (Blackport et al. 2009; Russell et al. 2009). The Paris Moraine is also considered to be 134 an important aggregate resource (Ontario Ministry of the Environment 2009). Delineating the 3D 135 spatial geometry of the Paris Moraine and associated deposits is important for accurately assessing its 136 economic and hydrogeologic value and potential, which in turn, can be used to inform source water 137 protection and groundwater resource management decisions.

\section{METHODS}

\section{Data Compilation}

A total of 1508 data points recording depth and occurrence of 7 different stratigraphic units were

141 integrated to produce this $165 \mathrm{~km}^{2}$ model. 263 of these data points came from moderate to high 142 resolution geologic logs from academic studies (8), and geotechnical reports (255), whereas the 143 remaining 1245 boreholes were obtained from the Ontario Ministry of the Environment water well 144 database (Figure 1). This resulted in a data density of 9.1 data points $/ \mathrm{km}^{2}$ for the entire study area.

145 When using lithology data to interpolate stratigraphic models, it is best to use only (or primarily) high 146 quality and reliable data. However, in this and many other cases, the use of low quality data from more 
147 regionally extensive databases is necessary to improve the distribution of data across the study area as 148 there were very few high-quality data points, and many of the moderate quality data were typically very 149 shallow (7 $\mathrm{m}$ or less) and clustered around local construction sites. As a result, the more regionally 150 extensive water well database (lower quality data) was used to provide information about the subsurface 151 lithology where high quality data were not available (MacCormack and Eyles 2010). To help reduce the 152 number of inaccurate water well data included within the model, only data with a location accuracy of 153 less than $100 \mathrm{~m}$, and elevation accuracies of approximately 3 meters or less were included. This 154 methodology of filtering water well data has been applied in other studies forced to rely heavily on 155 water well data (Gao et al. 2006; Puckering 2011). Removing inaccurate water well data prior to model 156 interpolation has been done in previous studies such as Logan et al. (2006).

\section{Lithologic and Stratigraphic Coding}

The sediment description data provided for each borehole record were reduced from 108 unique descriptions to 22 textural categories. Combining similar sediment descriptions, such as (sand, fine sand, sandy, silty sand, medium sand, etc.) into categories is necessary in order to gain a better sense of

161 the significant textural variability across a study area (MacCormack et al. 2005; Dumedah and

162 Schuurman 2008; Dunkle et al, 2016). In this study, 22 textural categories were then grouped into 163 assemblages representing 7 stratigraphic units: Bedrock, Undifferentiated tills, Port Stanley Till, 164 Ablation deposits, Wentworth Till, Kame deposits, and Outwash deposits. This was done by comparing 165 the descriptions within the boreholes to the regional stratigraphic framework and assigning stratigraphic 166 units depending on the thickness and sequence of sediment descriptions within each borehole (Figure 2; 167 Table 1). Bedrock was assigned to the base of boreholes that indicated bedrock or solid rock had been 168 encountered and was drilled for at least $1 \mathrm{~m}$. The Undifferentiated tills unit was used where till or 169 diamict identified in the borehole records did not fit stratigraphically or lithologically with the other till 
170 units. Karrow $(1968,1974)$ suggests that finding till deposits older than the Port Stanley or Wentworth

171 Tills within the Paris Moraine is likely. However, the water well data typically do not contain

172 sufficiently detailed sediment description to accurately identify and differentiate these older till/diamict

173 units within the existing regional till stratigraphic framework (Table 1). The Port Stanley Till is

174 identified where the borehole records identified a silty sandy till, or similar description at surface or at a

175 relatively shallow depth below surface and in the NW sector of the study area (Table 1; Karrow 1968;

176 Russell 2009). Ablation deposits were identified as stratified sand and gravel typically found in a

177 stratigraphically similar position as the Port Stanley Till (Table 1). The Wentworth Till is a sandy to

178 silty till unit and is typically found in the SE sector of the study area (Table 1; Karrow 1968; Russell

179 2009). Above the Wentworth Till and primarily along the moraine and back slope in the SE sector are

180 numerous isolated and discontinuous packages of sand and gravel that have been identified as kame

181 deposits (Table 1; Cowan 1975; Karrow 1987). The uppermost stratigraphic unit is a more extensive

182 package of stratified sand and gravel identified throughout the study area as outwash deposits associated

183 with the stagnation and final retreat of the Laurentide Ice Sheet from this region (Table 1; Karrow 1987;

184 Russell et al. 2009). All borehole data were coded with picks identifying the elevation of the top contact

185 for each stratigraphic unit (Figure 2). If a stratigraphic unit was determined to be missing within a

186 borehole, the unit's top and base elevations were assigned the top elevation of the underlying horizon

187 resulting in a zero thickness, except if the missing unit(s) occurred at the bottom of the well, in which

188 case they were not recorded.

189 Kriging and the Use of Variography

190 Borehole data were interpolated using the kriging algorithm in RockWorks15 (a geological 191 modelling software package; www.rockware.com) to predict the vertical and horizontal distribution and 192 overall geometry of each stratigraphic unit. Due to the substantial differences in the spatial extent of the 
193 stratigraphic units, it was necessary to produce modelled surfaces for the top and base of each unit. For 194 example, the kame deposit is often laterally discontinuous so that its top surface cannot always be used 195 to define the base of the overlying outwash deposit.

196 Kriging is the most common algorithm used to interpolate geologic data (Kravchenko and Bullock 197 1999; Johnston et al., 2001; Jones et al. 2003; Kravchenko 2003; Mueller et al., 2004). This 198 geostatistical algorithm is capable of considering the spatial proximity of the observed data values (i.e. 199 depth and occurrence of the 7 stratigraphic units) as well as incorporate statistical properties of the 200 measured observations into the calculations of the predicted value (Isaaks and Srivastava 1989). This is 201 achieved by utilizing a variogram to provide additional information on the spatial autocorrelation of the 202 observed stratigraphic units with respect to the model grid nodes (Johnston 2001; Isaaks and Srivastava 203 1989). This provides an effective method of quantifying the similarity (or dissimilarity) between data 204 points with respect to distance (Cressie 1993; Logan et al. 2006, Chiles and Delfiner 2012).

205 The variogram is defined by the following equation;

$$
\gamma_{h}=\frac{\sum_{i}^{n-h}\left(x_{i}-x_{i}+h\right)^{2}}{2_{n}}
$$

The basic function of a variogram is to illustrate the semi-variance between two data points ( $\mathrm{X}$ at locations $\left\{x_{i}\right\}$ and $\left.\left\{x_{i+h}\right\}\right)$ over varying lag distances $(h)$ (Houlding 2000). This equation calculates the sum of the squared differences between pairs of points separated by distance. The number of points used in the comparison is $n$, therefore $n-h$ represents the number of comparisons (Davis 2002). 
213 correlation coefficient) were analyzed to assess the impact of subdividing the regional model on the

214 interpolation of each stratigraphic unit within each sub-model.

\section{Subdividing the Model}

Interpolating and modelling complex geological environments within a single model is often

217 very difficult, as such deposits typically include a substantial amount of natural (real) variability that

218 modeling algorithms are unable to account for (Keefer 2007; Logan et al. 2006). Conventional

219 geostatistical algorithms, such as kriging, require the assumption that the data being interpolated is

220 stationary, such that the variance and mean are the same throughout the model domain (Weissmann and

221 Fogg 1999; Davis 2002). When interpolating data across a glaciated region, it is unlikely that the

222 assumption of stationarity will remain valid considering the dynamic nature of these depositional

223 environments that result in both variable sediments at surface and a complex subsurface stratigraphy

224 (Weissmann and Fogg 1999; Babak et al. 2014). Thus, to improve the results of the regional model

225 interpolation, the study area was subdivided into regions of high and low complexity (variability) that

226 were analyzed independently. The regional model area was divided into sub-models (representing zones

227 of local stationarity) by assessing the data variability and geological complexity within the context of the

228 regional conceptual model. The Original Regional Model domain was subdivided into 3 sub-model

229 zones (Figure 1) by comparing changes in the lateral facies variability at depth in the borehole data set

230 (Figure 2) with stratigraphic and physiographic information from previous scientific publications (Table

231 1; Karrow 1968; Sadura et al. 2006; Russell et al. 2009). These publications typically include details on

232 the spatial extent of these different environments at surface as well as typical stratigraphic units

233 associated with each environment based on surficial mapping, borehole records and ground penetrating

234 radar datasets. 
Subsurface sediments in Zone 1 are composed of a series of diamict units overlain in many areas

236 by channelized fans of outwash sand and gravel. Zone 1, which encompasses outwash and till plain

237 physiographic elements at surface was identified as a sub-model because the stratigraphic layers in this 238 region tend to be more continuous and laterally extensive in comparison to the neighbouring hummocky 239 deposits of the moraine. Zone 2 is typically very hummocky at surface with a complex internal 240 stratigraphy of Wentworth Till at surface, older till(s) at depth, as well as isolated outwash, kame, and 241 ablation deposits. Zone 2 broadly corresponds to the elongated form and geometry of the Paris Moraine 242 and will likely result in data from the stratigraphic units being correlated in a direction along the length 243 of the moraine and not in the direction of ice movement as expected for the outwash and till plain 244 sediments (Figure 1). Zone 3 encompasses the area to the southeast of the Paris Moraine. These 245 deposits are distinct from the main moraine body and modeled independently due to the highly variable 246 and complex nature of the subsurface sediments and stratigraphic units in this area. The complexity of 247 the Zone 3 deposits (Figure 1) within this region are the result of sediment reworking by gravity and 248 glaciofluvial processes and drainage water ponding between the topographic highs of the Paris Moraine 249 and nearby Galt Moraine.

254 (herein referred to as range), direction of range, sill, type of variogram model, and correlation coefficient

255 varied for each sub-model. A grid spacing of $100 \mathrm{~m}$ x $100 \mathrm{~m}$ in the $\mathrm{X}$ and $\mathrm{Y}$ directions respectively was 256 used for each model. This grid node spacing was chosen to ensure that our models were able to capture 
257 the smaller-scale structures of the kame and outwash deposits, while not being too computationally 258 intensive. This produced a total of 615,600 grid nodes covering the $165 \mathrm{~km}^{2}$ study area, which offered 259 good resolution for defining the spatial extent of each stratigraphic unit.

\section{Re-Combining the Sub-Models}

261 Once all the sub-models were interpolated, the upper and lower grid surfaces of each

262 stratigraphic unit were joined together using the Grid Editor in Rockworks15. The stratigraphic units 263 were joined with the respective stratigraphic units in neighbouring sub-model domains to form 264 continuous layers over the entire Original Regional Model domain. There were generally sufficient data 265 points along the common boundaries between the sub-models to permit adjacent models to be 266 seamlessly recombined. Where stratigraphic unit grids did not align across sub-model boundaries, a 267 local grid filter (4 grid cells x 4 grid cells) was applied to smooth the transition between the grids. Once 268 the grid surfaces from neighboring sub-model areas were joined together, the regional model was rebuilt 269 using the new grids for each stratigraphic unit (Figure 3).

\section{Comparing the Model Output Results}

To assess the impact that subdividing the regional model had on the model results, six variogram parameters were evaluated for the regional model and each of the sub-models:1) Distance of range, 2) Nugget, 3) Sill, 4) Type of variogram model, 5) Direction of range, and 6) Correlation coefficient of the variogram parameters as discussed below. The scale of the grids used to model the regional and submodel are the same, and the density of data for each zone are quite similar (10.8 data points $/ \mathrm{km}^{2}, 7.8$ 
279 data points $/ \mathrm{km}^{2}$, and 8.5 data points $/ \mathrm{km}^{2}$ for Zones 1,2 , and 3 respectively). Therefore the change in the 280 size of the modelled area in and of itself, is not expected to affect the variogram parameters.

281 Root Mean Square Error (RMSE) was used to compare the model output results from the 282 standard Original Regional Model and the proposed sub-models to the original observed/measured data 283 points. RMSE is a good comparative statistic for assessing model output as it provides a global 284 indication of how similar the interpolated values are to the observed/measured data point values 285 (MacCormack et al. 2013). When analyzing the RMSE statistics, a small RMSE value indicates that the 286 interpolated values for the output model are more similar to the observed data point values, whereas a 287 large RMSE value suggests that the interpolated model values are less similar to the observed data 288 points. Thus, RMSE values are used here to determine how well the model fits the observed data 289 values, with low RMSE values indicting a high degree of model accuracy (Zimmerman et al. 1999; 290 Davis 2002; Dille et al. 2003; Jones et al. 2003; Mueller et al. 2004).

$$
R M S E=\sqrt{\frac{\sum_{i=1}^{n}\left(\hat{Z}\left(s_{i}\right)-z\left(s_{i}\right)\right)^{2}}{n}}
$$

291 Where $\hat{Z}\left(s_{i}\right)$ is the interpolated value at the point $\left(s_{i}\right)$, and $z\left(s_{i}\right)$ is the observed (true) value from the 292 original dataset at that same location, and $n$ is the number of points within the input dataset.

\section{RESULTS AND DISCUSSION}

The goal of this study was to investigate if by subdividing the regional model domain, based on the data variability and our understanding of the geological framework and depositional environment, the

296 variogram produced for each sub-model would be more representative of the variability within the data 297 for each area, thus resulting in a more geologically realistic interpolation of the entire model domain. 
298 The regional 3D stratigraphic reconstructions were modelled using the same algorithm for both the 299 standard approach of modelling the entire regional domain at one time (Original Regional Model), and 300 the proposed methodology of combining sub-models of the regional domain (Subdivided Regional 301 Model); these reconstructions were then compared to one another (Figure 3). The kriging algorithm 302 used to interpolate data in each of the models is highly sensitive to the variogram model parameters 303 (Myers 1997). Therefore, the variogram parameters (distance of major range, nugget, sill, type of 304 variogram model, direction of major range, and correlation coefficient) from the Original Regional 305 Model and each of the sub-models are compared to provide additional insight into the difference in 306 model output.

\section{Comparing the Nature and Geometry of Stratigraphic Units}

Visually, there are substantial differences between the two models. The Subdivided Regional Model was able to characterize additional complexity and variability both at surface (Figure 3) and at depth (Figures 4, 5). The surficial outwash deposits of the Subdivided Regional Model are much less extensive, and constrained to the NW and SE corner of the model domain, which is more consistent with published surficial geology maps of the area (Figure 3C; Ontario Geological Survey 2003). The fence diagram shows that other stratigraphic units at depth are also less extensive across the domain, resulting in more complex geometry of units that pinch out or thicken in specific areas and at specific depths within the domain (e.g NW and EW panels on Figure 4); this more complex geometry is thought to be more geologically realistic than the simpler 'layer-cake' model of the Original Regional Model, considering the sediment heterogeneity encountered in glacial deposits in general (Stephenson et al. 1988) and in this area in particular (Blackport et al. 2009; Russell et al. 2013; Arnaud et al. this volume). 
320 The variable geometry of these units is an important consideration in the context of both local and 321 regional hydrogeological investigations where different unit geometry (with distinct lithology 322 characteristics) can affect overall recharge rates of groundwater, travel time and distribution of 323 contaminants. Improving model predictions of the form and geometry of highly heterogeneous areas 324 like this may help to identify where windows in aquitard materials exist, which may compromise the 325 integrity of the aquitard and water quality in the underlying aquifer.

Notably, there are also significant differences in the geometry of the sediment-bedrock interface 327 between the Original Regional Model and the Subdivided Regional Model outputs (Figure 4, 5), with 328 significantly more relief on the bedrock surface and better constrained buried bedrock valleys in the 329 Subdivided Regional Model compared to the Original Regional Model. This variable sediment bedrock 330 interface is consistent with the variable bedrock surface topography and the relatively deep and well331 defined buried bedrock valleys documented previously (Karrow 1968, 1987; Gao et al. 2006; Cole et al. 332 2009) and observed in recently drilled boreholes within the study area (Steelman et al. this volume). 333 Relief on the bedrock topography surface is important in both local and regional groundwater 334 applications, as it has an impact on the distribution of recharge to underlying bedrock aquifers. 335 Modeling the geometry and distribution of the glacial deposits infilling the incised bedrock valleys with 336 respect to their hydrogeologic properties allows the user to better understand groundwater migration 337 pathways and the potential for increased groundwater recharge of bedrock aquifers.

338 Although the Paris Moraine (Zone 2) in the Subdivided Regional Model is dominated by till units, 339 specific units of coarse-grained materials (outwash, kame or ablation deposits) within the moraine tend 340 to be thicker and more spatially constrained compared to that in the Original Regional Model (Figure 5). 341 This is indeed more consistent with the subsurface stratigraphy of the moraine identified as 
342 heterogeneous and variable in regional studies based on water well records and geotechnical reports as 343 well as more local studies based on both water well records and recovered sediment core (Blackport et 344 al. 2009; Russell et al. 2013; Arnaud et al. this volume). Sediment composition in water well records of 345 the Paris Moraine in the area surrounding Guelph for example suggests there is approximately 30\% 346 gravel, with relatively less sand $(\sim 10 \%)$ and mud $(<10-15 \%)$ that make up the Paris Moraine subsurface 347 stratigraphy (Russell et al. 2013). Cores recovered in the moraine together with cross section through the 348 moraine in the Guelph area also have laterally restricted sequences of coarse grained materials adjacent 349 (within 100's of $\mathrm{m}$ ) to boreholes dominated by diamict (Arnaud et al. this volume). The lateral 350 continuity of units within Zones 1 and 3 appear to have been more impacted by sub-dividing the model 351 domain than those within the Paris Moraine. Generally, the geologic units within the Subdivided 352 Regional Models are more laterally discontinuous, and have greater variability in unit thicknesses 353 (Figure 5), which is also consistent with previous findings based on standard geological cross sections 354 through the area (Blackport et al. 2009; McGill 2012; Arnaud et al. this volume), where subsurface 355 heterogeneity, lateral discontinuity of geologic units and/or the relief on the underlying bedrock surface 356 leads to rapid changes in unit thicknesses. For example, the basal diamict that underlies the outwash 357 plain is not always preserved (McGill 2012), and the regional Catfish Creek Till thickens considerably 358 from $<5 \mathrm{~m}$ to over $25 \mathrm{~m}$ as it infills a topographic low in the underlying bedrock surface (Steelman et al. 359 this volume).

\section{Comparing Range Values}

362 It is typically assumed that a longer range is better because it indicates that the data values were 363 similar to one another over greater distances. However, in areas where the data are more variable over 364 shorter distances, a variogram with a shorter range of correlation would likely produce a more realistic 
365 model result. The variogram ranges for the Original Regional Model varied between $1818.9 \mathrm{~m}$ 366 (Outwash base grid) and $2496 \mathrm{~m}$ (Ablation base grid) with an average range of $2210.8 \mathrm{~m}$ for the entire 367 model (Table 2). The ranges for the subdivided models tended to be shorter than those of the Original 368 Regional Model (Tables 2, 3, 4, and 5). The range values in the Zone 1 sub-model varied between $369 \quad 1197.1 \mathrm{~m}$ for the Outwash base grid and $1712.9 \mathrm{~m}$ for the Undifferentiated tills top grid with an average 370 range of $1585.9 \mathrm{~m}$ for the entire sub-model (Table 3). The Zone 2 sub-model ranges varied between $371 \quad 1599.3 \mathrm{~m}$ for the Wentworth Till base grid and $2182.2 \mathrm{~m}$ for the Undifferentiated till base grid, with an 372 average range of $1973.8 \mathrm{~m}$ for the entire model (Table 4). The range values for the stratigraphic units 373 within the Zone 3 sub-model varied between $1284.9 \mathrm{~m}$ for the Wentworth Till base grid and $1809.9 \mathrm{~m}$ 374 for the Kame base grid, with an average range of $1531.4 \mathrm{~m}$ for all of the stratigraphic units within this 375 sub-model (Table 5). Glacial ice margin advances and retreats over the study area have led to a complex interfingering 377 of glacial deposits of variable texture. Regionally, the subsurface stratigraphy has been characterized as 378 consisting of alternating diamict and stratified sediment such as sand, gravel and mud; the former 379 representing ice advances, whereas the latter records ice margin retreat and glaciofluvial and 380 glaciolacustrine processes in ice proximal to ice marginal settings. However, local studies of the 381 subsurface stratigraphy to date have demonstrated that the subsurface stratigraphy is more variable with 382 laterally discontinuous stratigraphic units (Blackport et al. 2009, Russell et al. 2013; Arnaud et al. this 383 volume). This heterogeneity is attributed to the dynamic interplay of glacial processes over time, 384 namely glaciofluvial and glacial erosion and variable preservation of previously deposited glacial 385 sediments, as well as the spatially and temporally varied distribution of glaciofluvial networks and 
386 glaciolacustrine ponding that would have occurred in different places over time as the ice margin melted 387 and glaciofluvial and ice marginal processes modified the pre-existing deposits.

\section{Comparing Nugget Values}

the Paris Moraine (Karrow 1968; Barnett 1996; Sadura et al. 2006; Russell et al. 2009; Blackport et al. 2009; Arnaud et al. this volume), variograms with a shorter range are probably geologically more realistic, characterizing the true variability within the subsurface. By subdividing the study area prior to interpolation, the average range lengths for the stratigraphic units were decreased between $11 \%$ and $31 \%$ compared to the original regional model where all data were lumped rather than subdivided (Tables 2, 3, 4 and 5). A lower range value does not suggest that one model is necessarily better than another, but rather that the variability has been constrained to the local sub-model areas, and ensuring the stratigraphic variability characteristic to each sub-model zone was preserved.

The variogram nugget represents the amount of very short range (zero distance) variability that cannot be accounted for in the variogram model and is associated with unexplained errors in the data or sampling procedures (Krajewski and Gibbs 1996). The nugget is often the result of sampling errors or geological variability that is occurring on a smaller scale than the data point spacing and is measured in units squared (Davis 2002). Although it would be ideal to have a variogram without any nugget effect, this is typically uncommon in geological investigations (Krajewski and Gibbs 1996; Davis 2002). The nugget for the Original Regional Model ranged from 0 to $25.3 \mathrm{~m}^{2}$ for the 7 stratigraphic units, with an average nugget of $14.9 \mathrm{~m}^{2}$ for all units (Table 2). The Zone 1 sub-model had nugget values that ranged from 0 to $15 \mathrm{~m}^{2}$, with an average nugget of $6.9 \mathrm{~m}^{2}$ (Table 3). The Zone 2 sub-model had nugget values that ranged from 0 to $15.6 \mathrm{~m}^{2}$, and an average nugget of $7.5 \mathrm{~m}^{2}$ (Table 4). The Zone 3 sub-model 
408 produced variograms with nuggets ranging from 0 to $9.9 \mathrm{~m}^{2}$, and an average nugget of $4.7 \mathrm{~m}^{2}$ (Table 5 ).

409 Subdividing the regional model resulted in lower nugget values for each of the sub-models as average

410 nugget values were reduced by $54 \%, 50 \%$, and $68 \%$ for the Zone 1,2 , and 3 sub-models, respectively.

411 These results suggest that the variograms were able to better characterize more of the data (resulting in

412 less unexplained variability) when the subdivided models were interpolated separately. Essentially,

413 the sub-models are better at capturing smaller scale variability that is likely related to the depositional

414 conditions of each zone, thus resulting in less unexplained variability. The lower nugget values indicate

415 that by subdividing the regional model based on data variability and geologic knowledge, the amount of 416 unexplained variability within the models was reduced for each sub-model.

\section{Comparing Sill Values}

418 The sill represents the amount of variability observed between the data points at the variogram

419 range. Theoretically, if the distance between the sample points is zero, the value at each data point will 420 be compared with itself and therefore the variance would also be zero. As the distance between points 421 get slightly larger, so too would the difference in values. At some distance, the points are so far apart 422 that they are no longer spatially related. At this point, the variance (gamma), which is measured in units 423 squared, between successive data points no longer increases and it is referred to as the sill. If the sill is 424 reached at a low gamma value, this indicates that there tends to be less variability between data point 425 values. In contrast, if the sill is reached at a high gamma value, then there is generally more variability 426 between data point values. Statistically, it is better to have a variogram with a low sill value, which 427 indicates that there is lower variability between the data points even up to the distance at which the 428 points are no longer statistically similar to one another (Krajewski and Gibbs 1996). However, 429 geologically, a low or high sill value allows the level of variability within the stratigraphic dataset to be 
430 established, which in turn provides information on the subsurface variability within each of the sub 431 model zones.

432 The Original Regional Model variogram produce d sills ranging from $36.4-144.2 \mathrm{~m}^{2}$, with an 433 average sill of $103.5 \mathrm{~m}^{2}$ (Table 2). The Zone 1 sub-model variograms produced sills ranging from 10.6 $434-90.2 \mathrm{~m}^{2}$, and an average sill of $57.2 \mathrm{~m}^{2}$ (Table 3 ). The Zone 2 variogram sill values ranged from 20.6 $435-98.8 \mathrm{~m}^{2}$, with an average sill of $66.7 \mathrm{~m}^{2}$ (Table 4). The Zone 3 sub-model variogram sill values ranged 436 from $19.2-83.1 \mathrm{~m}^{2}$, with an average sill value of $45.2 \mathrm{~m}^{2}$ (Table 5). The sub-model variograms had 437 lower average sill values than the Original Regional Model (103.5 $\mathrm{m}^{2}$; Table 2). A lower sill value does 438 not suggest that one model is better than another, but rather that there is less variability within the data 439 used to model the variogram. The results of this study indicate that there is less variability between the 440 data points within the sub-model variograms than in the Original Regional Model variogram 441 representing the entire model domain. The lower sill values are consistent with our current 442 understanding of the local geology: Zone 1 and Zone 3 are characterized by the drumlinized till plain 443 and outwash plain, and have relatively consistent subsurface stratigraphy dominated by till and stratified 444 sediments respectively, whereas the slightly larger sill value observed for Zone 2 is representative of the 445 more heterogeneous deposits of the Paris Moraine (Arnaud et al. this volume). By subdividing the 446 regional model into sub-models of similar data variability, the respective variograms were able to better 447 characterize the site variability and are more likely to produce a more realistic representation of the 448 volumes for each geologic unit.

\section{Correlation Coefficients}

450 The correlation coefficient is used to assess how well the variogram model matches the data, 451 which provides some information on the predictive capabilities of the interpolation parameters. The 
452 correlation coefficient is a measure between -1 and +1 , indicating that there is a perfect negative 453 correlation $(-1)$, no correlation $(0)$, or a perfect positive correlation $(+1)$ between the data points and the 454 variogram model. A correlation coefficient close to 1 indicates that the variogram was able to 455 accurately define the spatial relationship of the data points and that there is a good fit between the 456 observed data points and the variogram model that will be used to predict the grid surfaces; both of 457 which are extremely important in order to achieve an accurate interpolation result. The correlation 458 coefficient is therefore a useful statistic to help analyze how well the variogram model is able to match 459 the observed data, which provides some information on the predictive capabilities of the interpolation 460 parameters. In this study, we are interpolating the elevation of specific stratigraphic units, therefore the 461 correlation coefficient was used to assess how well the variogram model was able to predict the 462 elevation of the stratigraphic units at observed (borehole) locations.

The Original Regional Model produced correlation coefficients between 0.89 and 0.99 , with an 464 average of 0.96 for all grids (Table 2). The Zone 1 sub-model produced variogram models with better 465 correlation coefficients ranging from $0.98-1.0$, with an average of 0.98 (Table 3). The Zone 2 sub466 model correlation coefficients ranged between 0.97 and 1.0, with an average of 0.99 (Table 4). The 467 Zone 3 sub-model values ranged between 0.88 and 0.99 , with an average of 0.95 (Table 5). The Zone 1 468 and 2 sub-models both performed better than the Original Regional Model, whereas the Zone 3 sub469 model performed equally as well as the Original Regional Model. It is apparent that there is higher variability amongst the data of the Zone 3 sub-model due to the 471 lower average correlation coefficient. This may be due to the complex depositional conditions that 472 would have existed in this area during ice retreat and that include slumping of sediments along the Paris 473 Moraine back slope as the buttressing ice retreated from the area, as well as glaciofluvial reworking and 
474 ponding that would have occurred as the ice retreated to the position of the Galt Moraine to the SE. In 475 addition, some of the lower correlation coefficients observed in Zone 3 may be related to the difficulty 476 of identifying those units at depth (e.g. Port Stanley and Undifferentiated tills; Table 5). This may be 477 due to several factors including: i) the possibility that these lower tills were partially eroded and 478 therefore more randomly distributed, ii) the predominance of low quality data point in Zone 3, which 479 makes it difficult to distinguish between the various tills at depth, and iii) the relatively sparse coverage 480 of data points within portions of Zone 3.

481 It is likely that the lower correlation coefficient observed within the Zone 3 sub-model is causing 482 the lower correlation coefficient observed within the Original Regional Model, as both the Zone 1 and 2 483 sub-models produced variograms with better (higher) correlation coefficients (0.99 and 0.98 484 respectively; Tables 3 and 4) than the Original Regional Model (0.96; Table 2). Therefore, by 485 subdividing the regional model into sub-model areas, it was possible to limit the amount of influence 486 between the regions of increased variability observed within the Zone 3 sub-model, and the less variable 487 model areas of Zones 1 and 2. Developing a geologic model that more realistically characterizes the 488 stratigraphy and subsurface heterogeneity will ultimately provide a more robust framework for assigning 489 hydrogeologic parameters in groundwater flow models used in regional resource management or 490 contaminated site remediation applications (de Marsily et al. 2005).

\section{Optimal Variogram Model}

492 For the variogram to be used in the interpolation process, a variogram model must be fit to the 493 data to provide a prediction of the unknown values at specific locations. The Variogram model is 494 essentially a generalized mathematical equation that provides the best fit to the observed data (Isaaks 495 and Srivastava 1989; Gringarten and Deutsch 2001; Chiles and Delfiner 2012). There are a variety of 
496 variogram models (ie. spherical, exponential, linear, gaussian, nugget, hole-effect, and drift) that can be 497 applied to data depending on how quickly the data variability increases as the distance between data 498 points increases. Many software packages will automatically assign a spherical model when fitting a 499 variogram unless otherwise specified. For this study, variograms were fit using each type of variogram 500 model to determine which variogram model produced the best fit with the observed data points, had a 501 high correlation coefficient, and corresponded with our understanding of the spatial variability for each 502 specific stratigraphic unit (Gringarten and Deutsch 2001). A complete list of variogram models and 503 their implications to model output can be found in Isaaks and Srivastava (1989), Krajewski and Gibbs 504 (1996), Gringarten and Deutsch (2001), and Johnson (2001).

The Exponential variogram model most often provided the best fit for the stratigraphic unit datasets in this study. Exponential variogram models typically provide the best fit for datasets where the 507 variance increases quickly at short-distances and then gradually tapers off for data points that are further 508 apart (Gringarten and Deutsch 2001). This seems appropriate considering many stratigraphic units in 509 this study area are quite variable at short distances, however because these units are often dispersed 510 throughout the study area, the data tends to fit best with models with positive correlations that persist 511 below the sill for large horizontal distances, and often do not reach the expected sill variance. All of the 512 grid surfaces for the Original Regional Model were modelled using an Exponential variogram either 513 with or without a nugget (Table 2). Only three surfaces in the Zone 1 and 2 sub-models (outwash 514 deposit top in zones 1 and 2 and base in zone 1) were modelled with a Gaussian variogram model both 515 with and without a nugget (Tables 3 and 4). Gaussian variogram models typically provide the best fit 516 for datasets whose variance initially increases gradually, then begins to increase more rapidly as the 517 distance between points increases, which is likely considering the outwash deposits have a patchy 
518 distribution at the surface (Figure 3C; Krajewski and Gibbs 1996). The only other grid that used a 519 variogram model other than Exponential was the Ablation base grid in the Zone 3 sub-model, which 520 used a spherical model (Table 5). Spherical variogram models are characteristic of datasets where 521 variance initially increases linearly with increasing distance up to a well-defined sill, and are also 522 typically used for modelling properties with higher levels of short-range variability (Krajewski and 523 Gibbs 1996). In general, there was very little change in variogram type between the Original Regional 524 Model and the individual sub-models, and therefore, subdividing the regional model domain for this 525 study area was minimally impacted by the type of variogram selected.

\section{Variation in the Direction of Longest Variogram Range} In order to determine the direction for which the variogram range is the longest and produces the

531 when the regional model is subdivided, if dominant processes change from one area of the regional 532 model to the next. The direction of longest variogram range is also expected to be more closely aligned 533 for the top and base of geological units in a sub-model zone, as that zone will have been subjected to 534 specific depositional conditions and be associated with specific geological features that are directionally 535 more consistent, compared to the wide range of depositional conditions and anisotropy captured in a 536 regional model. Lower correlation between the top and base of thicker or more extensive units is 537 expected where the basal contact and the overlying sediment result from different processes (e.g. 538 glaciolacustrine sediments blanketing an irregular topography associated with the underlying 539 depositional regime). 
The results from the anisotropic variograms revealed that the direction of longest range changed

541 for some stratigraphic units when the regional model was subdivided into sub-models based on data

542 variability and geological context. For example, the top and bottom grid surfaces of the Kame deposit

543 for the Original Regional Model produced the longest ranges at N 135 and N 141 respectively. When

544 the variograms were produced for the subdivided models, the top and bottom grid surfaces of the Kame

545 deposits for the Zone 2 sub-model produced the longest ranges at N 7 and N 9 respectively, which 546 represents a 130 degree shift (Table 2 and 4). Kames can have a wide variety of ranges considering that

547 they are deposits that represent the internal drainage that was occurring on and within the ice (Benn and 548 Evans, 2010). The change in the direction of longest range between the Original Regional Model and 549 the Zone 2 sub-model highlights the variation of the kame deposits between the sub-model zones while 550 maintaining consistency within each sub-model zone.

557 of drumlins, the direction of ice flow and melt-water run-off in this study area (Karrow 1968, 1987;

558 Barnett 1992; Figure 6B; Table 3). There was also much greater consistency between the top and base 559 grids for each stratigraphic unit within Zone 2 (average difference of only 12.6 degrees; Figure 6C; 560 Table 4). Although the range direction for the Zone 2 sub-model stratigraphic units varied between $\mathrm{N} 7$ 561 and $\mathrm{N} 176$ (a 169 degree difference), the rose diagram for the Zone 2 sub-model (Figure 6C) shows that 
562 the direction of longest range for the majority of stratigraphic units were aligned in the direction of ice

563 movement and meltwater runoff to the NW. In contrast, the kame deposits and uppermost outwash

564 deposits of Zone 2 were aligned nearly N-S (Figure 6C, Table 4), which in some places is aligned with 565 the front edge of the Paris Moraine (Figure 1) and explains the 169 degree difference in range directions 566 for the different stratigraphic units of Zone 2. It is perhaps not surprising that kames are not consistent 567 with the rest of the data considering their deposition is related to glacial hydrology controlled by 568 localized ice configuration and drainage networks. In contrast, the Zone 3 sub-model showed 569 considerable variation in the direction of the unit variogram long axis. The directions ranged from $\mathrm{N} 8.6$ 570 to $\mathrm{N} \mathrm{177,} \mathrm{which} \mathrm{is} \mathrm{a} \mathrm{difference} \mathrm{of} 168.4$ degrees (Figure 6D; Table 5). This is consistent with the 571 palaeoenvironmental model for this area that suggests initial deposition and deformation by ice in the 572 SE-NW direction, further deposition by debris flows as the ice retreated and support of the moraine 573 sediment was removed, and lastly glaciofluvial and glaciolacustrine reworking of sediments along the 574 back slope of the Paris Moraine in the NE-SW direction as water drained between the Paris Moraine and 575 the adjacent Galt Moraine. The difference in direction between the top and base grid surfaces for each 576 unit was also significantly lower with an average difference of 54.4 degrees (Figure 6D; Table 5).

578 Regional Model appear quite different from one another (Figures 3, 4, 5). The most substantial 579 difference is in the Outwash deposit, which appears much less extensive in the Subdivided Model, and is 580 limited to two broad swaths; one in Zone 1 and one in the SE corner of the study area in Zone 3 (Figure 5813 ). Zone 2 of the subdivided model is characterized by more extensive tracts of Wentworth Till, kames 582 and minor outwash (Figure 3B), which are consistent with the distribution of Wentworth Till and gravel 583 identified in the surficial geology map (Figure 3C). The variation in the range direction between the top 
584 and bottom of the Outwash stratigraphic unit in the Original Regional Model was 40 degrees (Figure 585 6A; Table 2). However, when the Outwash unit was interpolated in the sub-model sections, the 586 variation between the top and bottom grids was a maximum of 20 degrees (Tables 2, 3, 4 and 5). The 587 reduced variation in range likely occurred because there was greater correlation between the direction of 588 longest range between the top and bottom grids of the stratigraphic units, which resulted in a more 589 localized and streamlined model representation of the Outwash deposits (Figure 3). In constrast, the 590 deposits within Zone 3 had much more directional variability than those of Zone 2 or 1 (Figure 6D). It 591 is likely that the greater directional variability of the stratigraphic units within Zone 3 significantly 592 affected the Original Regional Model variograms, resulting in more directional variation and greater 593 inconsistencies between top and bottom of each unit, therefore biasing the form and geometry of the 594 Outwash unit. By subdividing the regional model, it was possible to produce variograms that better 595 characterize the individual stratigraphic units within each zone, thus revealing the different degrees of 596 variability associated with each zone, reflective of depositional environments and spatial data.

In geological terms, the subdivided model variograms were able to capture the variability in flow 598 direction associated with each zone and thus better infer the resulting distribution of the Outwash 599 stratigraphic unit in those different meltwater drainage networks. In Zone 1, the direction of longest 600 variogram range is consistent with meltwater flow directions away from the ice margin and the Paris 601 Moraine and influenced by the NW-SE drumlin orientations of the pre-existing till plain. In Zone 2, the 602 direction of longest variogram range for the top and base of the outwash deposit varies by 20 degrees, 603 consistent with the likely more variable drainage patterns influenced by the chaotic hummocky 604 topography of the moraine. Lastly in zone 3, the direction of longest variogram shifts to a NNW-SSE 605 direction, which is perhaps capturing some of the predominant NW-SE drainage as well as some 
606 deflection of that flow towards the south as meltwater was routed between the Paris and adjacent Galt 607 moraines.

\section{RMSE Results}

609 Root mean square error results have been used in many studies as an effective method of 610 assessing the accuracy (i.e. how closely the model matches the observed points) of interpolated results 611 (Zimmerman et al. 1999; Davis 2002; Dille et al. 2003; Mueller et al. 2004). RMSE results were used in 612 this study to compare the model accuracy of the regional model interpolated using all the available data 613 (Original Regional Model) and the regional model produced by subdividing and interpolating sub614 models based on data complexity/variability (Subdivided Regional Model; Figure 3). The Subdivided 615 Regional Model produced a lower RMSE value (0.57) than the Original Regional Model (0.86). 616 Therefore, subdividing the regional model domain into sub-models produced a more accurate spatial 617 interpolation of the regional data.

Ideally, only data from high quality and reliable data sources would have been used. However, as is often the case in regional geological models, it was necessary to include variable quality data from regional databases due the size of the regional model domain, and the fact that the available moderate quality data were often clustered and did not penetrate very deep in the subsurface. It is likely that as additional high quality data becomes available for the model domain, the performance of the subdivided model variograms will improve further, thus having an even greater impact on the 3D stratigraphic model accuracy and an improved basis for informing hydrogeologic parameter variability. Stochastic modelling approaches could also be applied within sub-model zones to visualize and assess multiple model realizations and capture the variability in the model predictions (Kearsey et al. 2015). The next 627 step is to integrate this improved representation of the geologic spatial variability with hydrologic 
628 parameters to assess the effects on flow system conditions where water balance and hydraulic head 629 distributions from field and model outputs can be evaluated. This improved delineation of the 630 subsurface deposits within the Paris Moraine will in turn be useful for the management of groundwater 631 resources as source water protection policies are implemented in coming years.

\section{CONCLUSIONS}

634 The objective of this study was to determine if subsurface geological model accuracy could be 635 improved by splitting the regional model into multiple sub-models based on the degree of variability 636 observed between surrounding data points and our knowledge of the geological/depositional framework 637 from previous studies. The hypothesis is that by separating the regional model domain into sub-models 638 based on the data variability and our understanding of the geological context, a variogram can be 639 produced for each sub-model region that is more representative of variability within each area, thus 640 resulting in a more geostatistically appropriate and geologically realistic (cf. Karrow 1968) model 641 interpolation for the entire study area that can be used to better inform aggregate and groundwater 642 resource characterization studies (Weissmann et al. 1999; de Marsily et al. 2005).

643 The results showed that by interpolating the regional stratigraphic units within sub-models based on 644 the spatial variability within the data, the kriging algorithm was able to produce a more representative 645 variogram of the data. The Zone 1 and 2 sub-models produced variograms with lower ranges, more 646 consistent major axis directions, higher correlation coefficients, and lower sill and nugget values. This 647 is to be expected considering the stratigraphic units in Zones 1 and 2 are typically elongate and laterally 648 continuous deposits in the SE-NW direction for the outwash and drumlinized till plain deposits (Zone 1), 
649 recording the dominant meltwater and ice flow directions, and in the NE-SW direction along the Paris 650 Moraine (Zone 2). Thus, the variogram models for these sub-models were more constrained and able to 651 better characterize the observation data then when the data for the entire model domain was considered 652 as a whole. The Zone 3 sub-models produced variograms with the shortest ranges, lots of variability in 653 the major axis direction, and produced lower correlation coefficients. The Zone 3 sub-model data were 654 evidently more difficult for the variogram to characterize, suggesting that this area contains the most 655 variable and complex stratigraphy within the model domain. This variability is attributed to sediment 656 reworking by gravity and glaciofluvial processes, and drainage water ponding between the topographic 657 highs of the Paris Moraine and nearby Galt Moraine. Zone 3 likely requires additional high resolution 658 field data to help characterize this complexity or further subdivision to improve variogram parameters 659 and model outputs.

The results of this study reveal that when all of the data were modelled together as one large regional 661 model, the resulting variograms produced blended estimates of the variogram parameters. However, 662 when the Zone 3 sub-model data were modelled independently of the Zone 1 and 2 sub-models, the 663 variograms were better able to capture the subsurface characteristics of each zone. The increased 664 variability within Zone 3 attributed to the complex sediment reworking and variable glaciofluvial, 665 glaciolacustrine and ice marginal processes associated with ice margin retreat to the adjacent Galt 666 moraine was confined to Zone 3and did not impact the sub-models of the neighbouring zones. 667 Conversely, the data characteristics of the more laterally extensive and directionally consistent 668 stratigraphic units within the outwash and till plain of Zone 1 as well as the elongate form and geometry 669 of the stratigraphic units within the Paris moraine (Zone 2) sub-models were confined to those areas and 670 did not reduce the variability observed within the Zone 3 sub-model area. 
The proposed sub-model approach produces a more geologically realistic model of the study area

672 when compared with the regional model approach as evidenced by comparing the model results against

673 the regional surficial geology map (Ontario Geological Survey 2003) and previous subsurface studies in

674 this area (Karrow 1968, 1987; Blackport 2009; Arnaud et al. this volume). In the sub-model outputs,

675 various stratigraphic units, are laterally more constrained and their bounding surfaces, including that of

676 the underlying bedrock, exhibit more significant relief. This is consistent with subsurface observations

677 in the study area where tills are laterally discontinuous, stratified sediments are found in close proximity

678 to diamict within the moraine and the underlying bedrock surface is dissected by various well-defined

679 buried bedrock valleys. The sub-model results are also more consistent with what is generally known of

680 sediment landform associations in terrestrial glaciated landsystems, namely the relative lateral continuity 681 of facies in till and outwash plains and the relative variability of facies found in ice marginal or ice 682 contact sediments (Stephenson et al. 1988; Benn and Evans 2010). The integration of sub-models 683 provides a means to highlight the heterogeneity across the regional domain and avoids blending areas of 684 differing variability together, resulting in a more realistic characterization of the nature, geometry and 685 extent of geological and hydrogeological units within this complex depositional environment. This is 686 turn can improve the geological framework used in various groundwater flow modelling efforts, both in 687 site specific contaminant transport investigations or in regional susceptibility or groundwater supply 688 studies carried out in previously glaciated regions like Southern Ontario.

689 ACKNOWLEDGMENTS

We would like to thank Ontario Research Fund-Research Excellence (BLP, principal investigator 691 and EA, co-investigator) and the Natural Sciences and Engineering Research Council (Discovery Grant 692 to EA; Industrial Research Chair to BLP) for funding this research; Gregg Zwiers and the Grand River 
693 Conservation Authority for providing additional sources of data; Colin Gutcher, Kyle Press, Erica

694 Gilbeaut-Ryan, Katy Nesbitt and Ramita Kedia for careful data entry; and Mike McGill, Steve Sadura, 695 and Anna Best for their assistance in collecting field data. We would also like to thank the reviewers, 696 and Hazen Russell, guest editor, whose helpful suggestions and comments certainly improved the paper. 697

\section{REFERENCES}

699 Arihood, L.D. 2008. Processing, Analysis, and General Evaluation of Well-Driller Logs for Estimating 700 Hydrogeologic Parameters of the Glacial Sediments in a Ground-Water Flow Model of the Lake 701 Michigan Basin. Scientific Investigations Report, 2008-5184.

702 Arnaud, E., McGill, M., Trapp, A., Smith, J. E. 2017. Subsurface heterogeneity in the geological and 703 hydraulic properties of Quaternary glacial deposits, Guelph, Ontario. Canadian Journal of Earth 704 Sciences. Doi: 10.1139/cjes-2016-0161

705 Artimo, A., Sarapera, S., and Ylander, I. 2004. Utilization of 3-D Geologic Modelling for a Large-scale 706 Water Supply project in Southwestern Finland. Illinois State Geological Survey (IGSG) Open$707 \quad$ File Series 2004-8.

708 Atkinson, L.A. and Glombick, P.M. 2015. Three-Dimensional Hydrostratigraphic Modelling of the 709 710 Sylvan Lake Sub-Basin in the Edmonton-Calgary Corridor, Central Alberta. Alberta Geological Survey Open File Report 2014-10.

711 Babak, O., Bergey, P., \& Deutsch, C. V. 2014. Facies trend modeling for SAGD application at Surmont. $712 \quad$ Journal of Petroleum Science and Engineering, 119: 85-103. 
713 Bajc, A. F. \& Newton, M. J. 2005. 3D Modelling of Quaternary Deposits in Waterloo Region, Ontario: 714 A Case Study Using Datamine Studio Software. Three-Dimensional Geologic Modelling for 715 Groundwater Applications. Workshop Extended Abstracts, Geological Survey of Canada Open 716 File 5048.

Bajc, A.F., Burt, A.K., and Rainsford, D.R.B. 2011. Approaching a Decade of Three-Dimensional Mapping of Quaternary sediments in Southern Ontario; A Progress Report from the Ontario Geological Survey, Three-dimensional Geological Mapping for Groundwater Applications. Workshop Extended Abstracts, Geological Survey of Canada Open-File Report 6998.

Barnett, P.J. 1992. Quaternary Geology of Ontario: in Thurston, P.C., Williams, H.R., Sutcliffe, R.H. and Stott, M.T., eds., Geology of Ontario: Ontario Geological Survey Special, 4 Part 2:. 10111090.

Benn, D. I. and Evans, D.J.A. 2010. Glaciers and glaciation. $2^{\text {nd }}$ edition. Hodder Education, London.

725
Blackport Hydrogeology Inc., Blackport and Associates Ltd., and AquaResource Inc., 2009. Review of the State of Knowledge for the Waterloo and Paris/Galt Moraines. Report prepared for the Ontario Ministry of the Environment.

Chapman, L.J. and Putnam, D.F. 1984. The physiography of southern Ontario; Ontario Geological Survey, Special Volume 2.

Chiles, J.P., and Delfiner, P. 2012. Geostatistics: Modeling Spatial Uncertainty. $2^{\text {nd }}$ Ed. Wiley Series in Probability and Statistics. John Wiley and Sons Ltd. 
732 Cole, J., Coniglio, M., and Gautrey, S. 2009. The role of buried bedrock valleys on the development of 733 karstic aquifers in flat-lying carbonate bedrock: insights from Guelph, Ontario, Canada. $734 \quad$ Hydrogeology Journal, 17: 1411-1425.

735 Cowan, W.R. 1975. Quaternary geology of the Woodstock area, southern Ontario. Ontario Geological 736 Survey, Geological Report 119.

737 Cressie, N.A.C. 1993. Statistics for Spatial Data Revised Edition. New York: John Wiley \& Sons, Inc.

738 Davis, J. C. 2002. Statistics and data analysis and geology. John Wiley and Sons.

739 de Marsily, G., Delay, F., Goncalves, J., Renard, P., Teles, V., \& Violette, S. 2005. Dealing with spatial 740 heterogeneity. Hydrogeology Journal, 13: 161-183.

741 Dille, J. A., Milner, M., Groeteke, J. J., Mortensen, D. A., \& Williams, M. M. 2003. How good is your 742 weed map? A comparison of spatial interpolators. BioOne, 51: 44-55.

Dumedah, G. \& Schuurman, N. 2008. Minimizing the effects of inaccurate sediment description in borehole data using rough sets and transition probability. Journal of Geographical Systems, : 291-315.

Dunkle, K. M., Anderson, M. P. and Hart, D. 2016. New Ways of Using Well Construction Reports for Hydrostratigraphic Analyses. Groundwater, 54: 126-130.

Gao, C., Shirota, J., Kelly, R.I., Brunton, F.R., and Van Haaften, S. 2006. Bedrock Topography and Overburden Thickness Mapping, Southern Ontario. Ontario Geological Survey, Miscellaneous Release-Data 207. 
751 Goodchild, M. F. \& Haining, R. P. 2004. GIS and spatial data analysis: converging perspectives. Papers 752 in Regional Science, : 363-385.

753 Gringarten, E. \& Deutsch, C. 2001. Teacher's aide to variogram interpretation and modeling. $754 \quad$ Mathematical Geology, 4: 507-534.

755 Gunnink, J., Stafleu, J., Maljers, D., Hummelman, J. 2013. Hydraulic Parameterization of 3D 756 Subsurface Models: From Measurement-Scale to Model-Scale: Three-dimensional Geological 757 Mapping, Workshop Extended Abstracts, Minnesota Geological Survey Open File Report $758 \quad$ OFR-13-2.

759 Houlding, S. W. 2000. Practical Geostatistics: Modeling and Spatial Analysis. Germany: Springer$760 \quad$ Verlag.

761 Isaaks, E. H. \& Srivastava, R. M. 1989. An Introduction to Applied Geostatistics. New York: Oxford $762 \quad$ University Press.

763 Johnston, K., Ver Hoef, J. M., Krivoruchko, K., \& Lucas, N. 2001. Using ArcGIS Geostatistical 764 Analyst. USA.

765 Jones, N. L., Davis, R. J., \& Sabbah, W. 2003. A comparison of Three-dimensional interpolation 766 techniques for plume characterization. Groundwater, 41: 411-419.

767 Karrow, P. F. 1963. Pleistocene Geology of the Hamilton - Galt Area (Rep. No. 16). Ontario 768 Department of Mines.

769 Karrow, P.F. 1968. Pleistocene geology of Guelph area. Ontario Department of Mines, Geological $770 \quad$ Report 61. 
771 Karrow, P.F. 1974, Till Stratigraphies in parts of southwestern Ontario: Geological Society of America Bulletin, 85: 761-768.

773

774
Karrow, P.F. 1987. Quaternary Geology of the Hamilton-Cambridge Area, Southern Ontario. Ontario Geological Survey, Mine and Minerals Division, Report 255.

Karrow, P.F., Dreimanis, A., Barnett, P. 2000. A Proposed Diachronic Revision of Late Quaternary Time-Stratigraphic Classification in the Eastern and Northern Great Lakes Area. Quaternary Research, 54:1-12.

Kearsey T, Williams J, Finlayson A, Williamson P, Dobbs M, Marchant B, Kingdon A, Campbell D. 2015. Testing the application and limitation of stochastic simulations to predict the lithology of glacial and fluvial deposits in Central Glasgow, UK. Engineering Geology, 17:98-112.

Keefer, D. A. 2007. A framework and methods for characterizing uncertainty in geologic maps. Three Dimensional Geologic mapping for Groundwater Applications, Minnesota Geological Survey Open File Report 07-4.

Kessler, H., Lelliott, M., Bridge, D., Ford, F., Sibusch, H. G., Mathers, S. 2005. 3D geosciences models and their delivery to customers. Three-dimensional Geologic Mapping for Groundwater Applications.Geological Survey of Canada, Open File 5048.

Krajewski, S.A., Gibbs, B. L. 1996. Understanding Contouring: A practical guide to estimation and contouring using a computer and Basics of using variograms: Gibbs Associates, Industrial Ergonomics, Inc. 
790 Kravchenko, A.N., and Bullock, D.G. 1999. A comparative study of interpolation methods for mapping $791 \quad$ soil properties, Agron Journal, 91: $393-400$.

792 Kravchenko, A. N. 2003. Influence of spatial structure on accuracy of interpolation methods. Soil 793 Science Society of America Journal, 67: 1564-1571.

Logan, C., Russel, H. A. J., Sharpe D.R., Kenny, F. M. 2006. The role of GIS and expert knowledge in 3-D modelling, Oak Ridges Moraine, southern Ontario. in J.R.Harris (Ed.), GAC Special Paper 44: GIS for the Earth Sciences. St. John's: Geological Association of Canada, p. 519-542.

MacCormack, K.E., MacLachlan, J.C., and Eyles, C.H. 2005. Viewing the Subsurface in Threedimensions: Initial Results of Modelling the Quaternary Sedimentary Infill of the Dundas Valley, Hamilton, Ontario. Geosphere, 1: 23-31.

MacCormack, K. E. and Eyles, C. H. 2010. Enhancing the Reliability of 3D Subsurface Models through Differential Weighting and Mathematical Recombination of Variable Quality Data. Transactions in GIS, 14: 401-420.

MacCormack, K.E., Brodeur, J.J., Eyles, C.H. 2013. Evaluating the impact of data quantity, distribution, and algorithms selection on the accuracy of 3D subsurface models using synthetic grid models of varying complexity, Journal of Geographical Systems, 15: 71-88.

McGill, M. 2012. A sedimentological and geomorphological investigation of the Paris Moraine in the 
809 McLaughlin P.P., Tomlinson, J.L., Lawson, A.K. 2015. Attributing Groundwater Withdrawals to 810 Aquifers Using 3-D Geological Maps in Delaware, USA, Three-dimensional Geological 811 Mapping: Workshop Extended Abstracts, Alberta Energy Regulator/Alberta Geological Survey $812 \quad$ Special Report 101.

813 Myers, J.C. 1997. Geostatistical Error Management. New York: Van Nostrand Reinhold.

814 Mueller, T. G., Pusuluri, P. B., Mathias, K. K., Cornelius, P. L., Barnhisel, R. I., Shearer, S. A. 2004. 815 Map quality for ordinary kriging and inverse distance weighted interpolation. Soil Science $816 \quad$ Society of America Journal, : 2042-2047.

817 O'Connor, D.R. 2002. Report of the Walkerton Inquiry: Part 1 - The Events of May 2000 and Related 818 Issues. Toronto, Canada.

819 Ontario Geological Survey. 2003. Surficial geology of southern Ontario [GIS data]. Ontario Geological $820 \quad$ Survey, Miscellaneous Release - Data 128 - Revised.

821 Ontario Ministry of the Environment. 2009. EBR Review Response: Paris and Galt Moraines. Queen’s 822 Printer of Ontario, Canada.

823 Rockworks 15, Rockware. Software for visualizing subsurface data with popular tools such as maps, 824 logs, cross sections, fence diagrams, solid models and volumetrics. [https://www.rockware.com]

825 Russell, H.A., Cummings, D.I., Sharpe, D.R. 2009. Sedimentology of the Paris and Galt Moraines and 826 Hydrogeological Implications. Fieldtrip for the 2009 Joint Assembly. Geological Association of $827 \quad$ Canada. 
828 Russell, H. A. J., Bajc, A., Sharpe, D. R., and Cummings, D. I. 2013. Paris and Galt Moraines, southern 829 Ontario: depositional elements, paleoglacial implications, and hydrogeological applications; Geological Survey of Canada, Open File 7153; 1 sheet, doi:10.4095/292705

831 Sadura, S., Martini, I.P., Endres, A.L., Wolf, K. 2006. Morphology and GPR stratigraphic of a frontal 832 part of an end Moraine of the Laurentide Ice Sheet: Paris Moraine near Guelph, ON, Canada.

\section{4} Geomorphology, 75: 212-225.

Steelman, C.M., Arnaud, E., Pehme, P. and Parker, B.L. 2017. Geophysical, geological and hydrogeological characterization of a tributary buried bedrock valley in southern Ontario, Canadian Journal of Earth Sciences. doi: 10.1139/cjes-2016-0120

Stephenson, D., Fleming, A., Mickleson, D. 1988. Glacial deposits. In Back, W., Roshenshein, J. S., and

Thomason, J.F., and Keefer, D.A. 2011. Geologic Framework Modeling for groundwater Applications in Northeast Illinois. Three-dimensional Geological Mapping for Groundwater Applications: Workshop Extended Abstracts, Geological Survey of Canada Open-File Report 6998.

Weber, D., Englund, E. J. 1994. Evaluation and comparison of spatial interpolators II. Mathematical Geology, 26: 589-603.

Weissmann, G. S., \& Fogg, G. E. 1999. Multi-scale alluvial fan heterogeneity modeled with transition probability geostatistics in a sequence stratigraphic framework. Journal of Hydrology, 226: 4865. 
848 Weissmann, G. S., Carle, S. F., \& Fogg, G. E. 1999. Three $\square$ dimensional hydrofacies modeling based on 849 soil surveys and transition probability geostatistics. Water Resources Research, 35: 1761-1770.

850 Wycisk, P., Hubert, T., Gossel, W., \& Neumann, C. 2009. High-resolution 3D spatial modelling of 851 complex geological structures for an environmental risk assessment of abundant mining and 852 industrial megasites. Computers \& Geosciences, 35: 165-182.

853 Zimmerman, D., Pavlik, C., Ruggles, A., Armstrong, M. P. 1999. An experimental comparison of 854 Ordinary and Universal Kriging and inverse distance weighting. Mathematical Geology, 31: 375$855 \quad 390$. 
Table 1: Generalized Stratigraphy as Described by Previous Studies in this Region

\begin{tabular}{lll}
\hline Karrow 1968 & Karrow 1987-NW sector & Karrow 1987-SE sector \\
\hline Wentworth Till & Kame/ outwash & Kame/ outwash \\
ablation deposits & $\begin{array}{l}\text { Port Stanley } \\
\text { Kame/outwash/Maryhill }\end{array}$ & Wentworth Till \\
Middle till & Till & Till \\
Catfish Creek Till & Catfish Creek Till & Catfish Creek Till \\
Canning Till or & & \\
older & Canning Till or older & Canning Till or older \\
Bedrock & Bedrock & Bedrock \\
\hline
\end{tabular}

*Note: A major unconformity surface exists between the Silurian bedrock and overlying Quaternary 858 deposits 
Table 2: Variogram parameters for the Original Regional Model

\begin{tabular}{ccccccc}
\hline Unit & Direction & Range $(\mathbf{m})$ & Sill $\left(\mathbf{m}^{\mathbf{2}}\right)$ & $\begin{array}{c}\text { Nugget } \\
(\mathbf{m} 2)\end{array}$ & Type & $\begin{array}{c}\text { Cor. } \\
\text { Coef. }\end{array}$ \\
\hline Outwash Deposit top & 169 & 2000.3 & 36.4 & 0 & Exponential No nugget & 0.98 \\
Outwash Deposit base & 129 & 1818.9 & 70.7 & 10.9 & Exponential w/ nugget & 0.97 \\
Kame Deposit top & 141 & 2121.5 & 91.8 & 14.5 & Exponential w/ nugget & 0.94 \\
Kame Deposit base & 135 & 2109.5 & 95.4 & 15.1 & Exponential w/ nugget & 0.95 \\
Wentworth Till top & 3.9 & 2253.5 & 65.6 & 0 & Exponential No nugget & 0.99 \\
Wentworth Till base & 125 & 1957.1 & 78.2 & 12.3 & Exponential w/ nugget & 0.97 \\
Abblation top & 138 & 2448.1 & 124.1 & 20.1 & Exponential w/ nugget & 0.93 \\
Abblation base & 148 & 2496 & 130.1 & 22.2 & Exponential w/ nugget & 0.89 \\
Port Stanley top & 9.5 & 2344.7 & 138.7 & 25.3 & Exponential w/ nugget & 0.94 \\
Port Stanley base & 161 & 2343.3 & 137.3 & 23.5 & Exponential w/ nugget & 0.97 \\
Undifferentiated Till top & 160 & 2357 & 139.3 & 23.9 & Exponential w/ nugget & 0.98 \\
Undifferentiated Till base & 162 & 2380.9 & 144.2 & 25.2 & Exponential w/ nugget & 0.99 \\
Bedrock top & 126 & 2109.2 & 93.5 & 0 & Linear No nugget & 0.98 \\
\hline Average & $\mathbf{1 2 3 . 6 5}$ & $\mathbf{2 2 1 0 . 7 7}$ & $\mathbf{1 0 3 . 4 8}$ & $\mathbf{1 4 . 8 5}$ & & $\mathbf{0 . 9 6}$ \\
\hline
\end{tabular}

Table 3: Variogram parameters for the Zone 1 sub-model

\begin{tabular}{ccccccc}
\hline Unit & Direction & Range $(\mathbf{m})$ & Sill $(\mathbf{m} 2)$ & Nugget (m2) & Type & Cor. Coef. \\
\hline Outwash Deposit top & 125 & 1329.8 & 10.6 & 1.4 & Gaussian w/ nugget & 1 \\
Outwash Deposit base & 132 & 1197.1 & 74.8 & 0 & Gaussian No nugget & 0.98 \\
Kame Deposit top & 149 & 1634.5 & 88.3 & 14.7 & Exponential w/ nugget & 0.98 \\
Kame Deposit base & 148 & 1639.6 & 90.2 & 15 & Exponential w/ nugget & 0.98 \\
Wentworth Till top & 154 & 1535.4 & 25.2 & 4.2 & Exponential w/ nugget & 0.99 \\
Wentworth Till base & 122 & 1506.2 & 35.6 & 5.3 & Exponential w/ nugget & 0.98 \\
Abblation top & 145 & 1694.6 & 106.5 & 17.6 & Exponential w/ nugget & 0.98 \\
Abblation base & 142 & 1688.1 & 108.3 & 17.7 & Exponential w/ nugget & 0.98 \\
Port Stanley top & 145 & 1701 & 107.7 & 16.8 & Exponential w/ nugget & 0.98 \\
Port Stanley base & 144 & 1702 & 101.8 & 16.6 & Exponential w/ nugget & 0.98 \\
Undifferentiated Till top & 144 & 1712.9 & 103.2 & 17 & Exponential w/ nugget & 0.98 \\
Undifferentiated Till base & 149 & 1687.3 & 100.5 & 16.4 & Exponential w/ nugget & 0.98 \\
Bedrock top & 121 & 1588 & 43.4 & 6.4 & Exponential w/ nugget & 0.99 \\
\hline Average & $\mathbf{1 4 0 . 0 0}$ & $\mathbf{1 5 8 5 . 8 8}$ & $\mathbf{7 6 . 6 2}$ & $\mathbf{1 1 . 4 7}$ & & $\mathbf{0 . 9 8}$ \\
\hline
\end{tabular}


Table 4: Variogram parameters for the Zone 2 sub-model

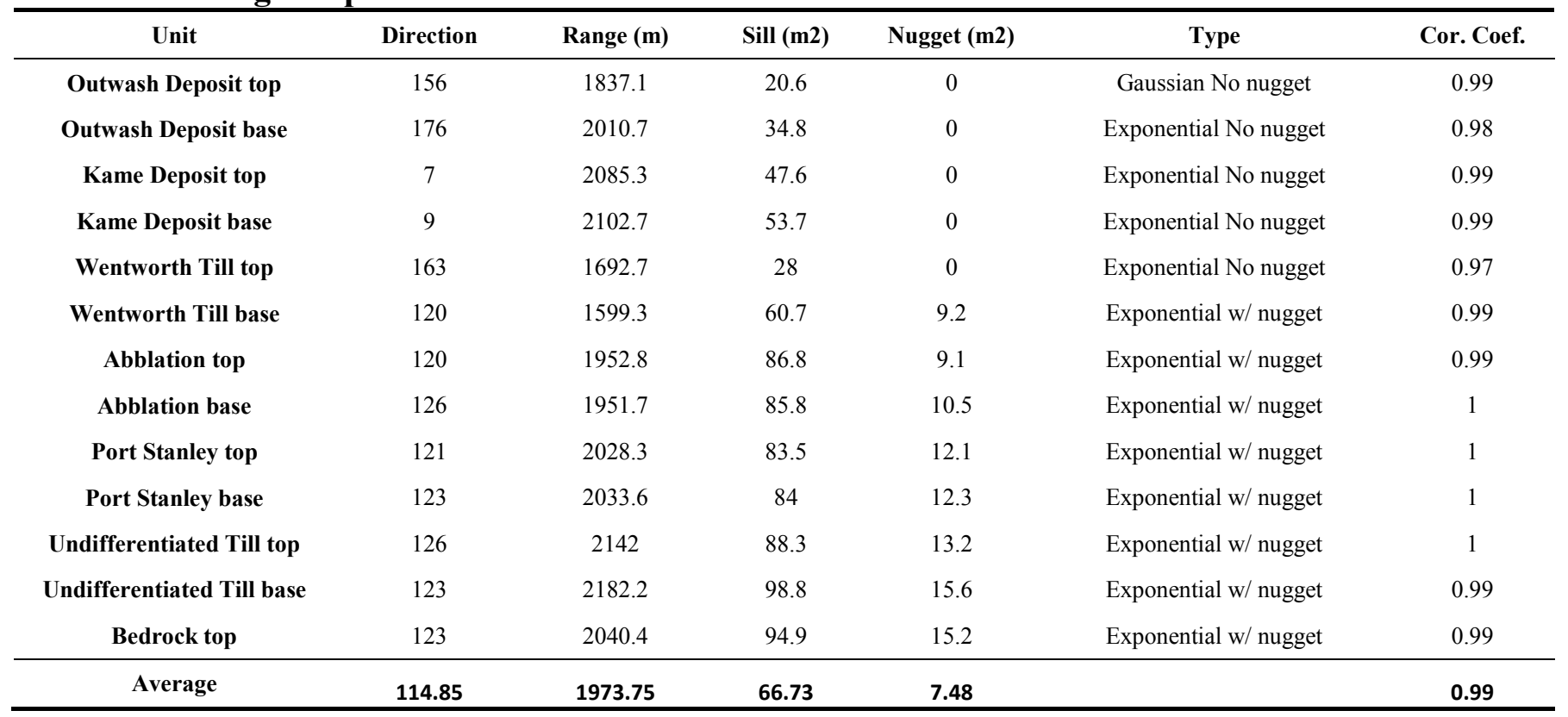

Table 5: Variogram parameters for the Zone 3 sub-model

\begin{tabular}{ccccccc}
\hline Unit & Direction & Range $(\mathbf{m})$ & Sill $(\mathbf{m} 2)$ & Nugget $(\mathbf{m} 2)$ & Type & Cor. Coef. \\
\hline Outwash Deposit top & 146 & 1410.8 & 19.2 & 2.6 & Exponential w/ nugget \\
Outwash Deposit base & 156 & 1522.4 & 39.3 & 6.4 & Exponential w/ nugget \\
Kame Deposit top & 8.6 & 1809.4 & 54.5 & 0 & Exponential No nugget \\
Kame Deposit base & 177 & 1809.9 & 83.1 & 0 & Exponential No nugget \\
Wentworth Till top & 39 & 1772.1 & 60.1 & 0.98 & Exponential No nugget \\
Wentworth Till base & 116 & 1284.9 & 35.9 & 6.6 & Exponential w/ nugget \\
Abblation top & 98 & 1390.8 & 43.6 & 9.9 & Exponential w/ nugget \\
Abblation base & 121 & 1504.4 & 41.5 & 0.98 & 0.99 \\
Port Stanley top & 124 & 1553.6 & 40.8 & 6.4 & Spherical No nugget \\
Port Stanley base & 83 & 1417.1 & 36.1 & 7.6 & Exponential w/ nugget \\
Undifferentiated Till top & 95 & 1415.6 & 35.3 & 7.2 & Exponential w/ nugget \\
Undifferentiated Till base & 102 & 1501.2 & 46.1 & 6.4 & Exponential w/ nugget \\
Bedrock top & 107 & 1515.7 & 52.4 & 7.8 & Exponential w/ nugget \\
\hline Averages & $\mathbf{1 0 5 . 5 8}$ & $\mathbf{1 5 3 1 . 3 8}$ & $\mathbf{4 5 . 2 2}$ & $\mathbf{4 . 6 8}$ & Exponential w/ nugget & 0.94 \\
\hline
\end{tabular}




\section{$711 \quad$ List of Figures}

712 Figure 1. Map of the Regional Model Domain, data point locations and locations of cross sections (A$713 \mathrm{~A}^{1}, \mathrm{~B}-\mathrm{B}^{1}$, and $\mathrm{C}-\mathrm{C}^{1}$ ). There are 1245 lower quality data points (red dots) from the water well database, 714263 moderate quality data points (yellow dots) from more reliable sources such as cored boreholes and 715 geotechnical reports and 6 high quality data points (green dots) from related research of the co-authors. 716 The three sub-model regions are delineated with white lines and identified as Zone 1, Zone 2, and Zone 717 3. Note that Zone 2 broadly coincides with the Paris Moraine. Coordinates are in UTM zone $17 \mathrm{~N}$, 718 Datum: NAD83.

719 Figure 2. Three-dimensional borehole representation of the data distribution and regional stratigraphy. 720 The vertical exaggeration of this model is $20 \mathrm{x}$.

721 Figure 3. Three-dimensional geological models of A) the Original Regional Model for which all the 722 data was interpolated, and B) the Subdivided Regional Model for which the 3 sub-models were 723 interpolated independently and then recombined. Models have a vertical exaggeration of 10x. C) 724 Surficial geology map of the study area for comparison with model outputs, note the improved 725 correlation between the surficial geology map and the Subdivided Regional Model. Note that orange 726 and yellow in A) and B) represent the sand and gravel (undifferentiated) of the outwash and kame 727 stratigraphic units, whereas orange and yellow in C) represent gravel and sand respectively. Map in C) 728 created using ESRI ArcMap 10.1 and data from Ontario Geological Survey (2003); white lines represent 729 the sub-model boundaries defined in Figure 1; black hatched lines represent the location of the cross730 sections in Figure 4. 
731 Figure 4. Fence diagram through A) the Original Regional Model, and B) the Subdivided Regional 732 Model. Both fence diagrams have a vertical exaggeration of 20x.

733 Figure 5. Cross sections through the model domain highlighting the difference in output based on a 734 single (original model) versus a multiple (subdivided model) variogram. See Figure 1 for location of 735 transects. Cross section distances: $A-A^{1}=18.5 \mathrm{~km} ; \mathrm{B}-\mathrm{B}^{1}=12.5 \mathrm{~km} ; \mathrm{C}-\mathrm{C}^{1}=11.1 \mathrm{~km}$. All cross sections 736 have a vertical exaggeration of 20x.

737 Figure 6. Rose diagrams indicating the direction of longest variogram range correlation from Tables 2738 5, with red line representing the average: A) the Original Model, B) Zone 1 sub-model, C) Zone 2 sub739 model, and D) Zone 3 sub-model.

\section{List of Tables}

743 Table 1: Generalized stratigraphy as described by previous studies in the region. A major unconformity 744 surface exists between the Silurian bedrock and overlying quaternary deposits.

745 Table 2: Variogram Parameters for the Original Regional Model.

746 Table 3: Variogram Parameters for the Zone 1 Sub-model.

747 Table 4: Variogram Parameters for the Zone 2 Sub-model.

748 Table 5: Variogram Parameters for the Zone 3 Sub-model. 


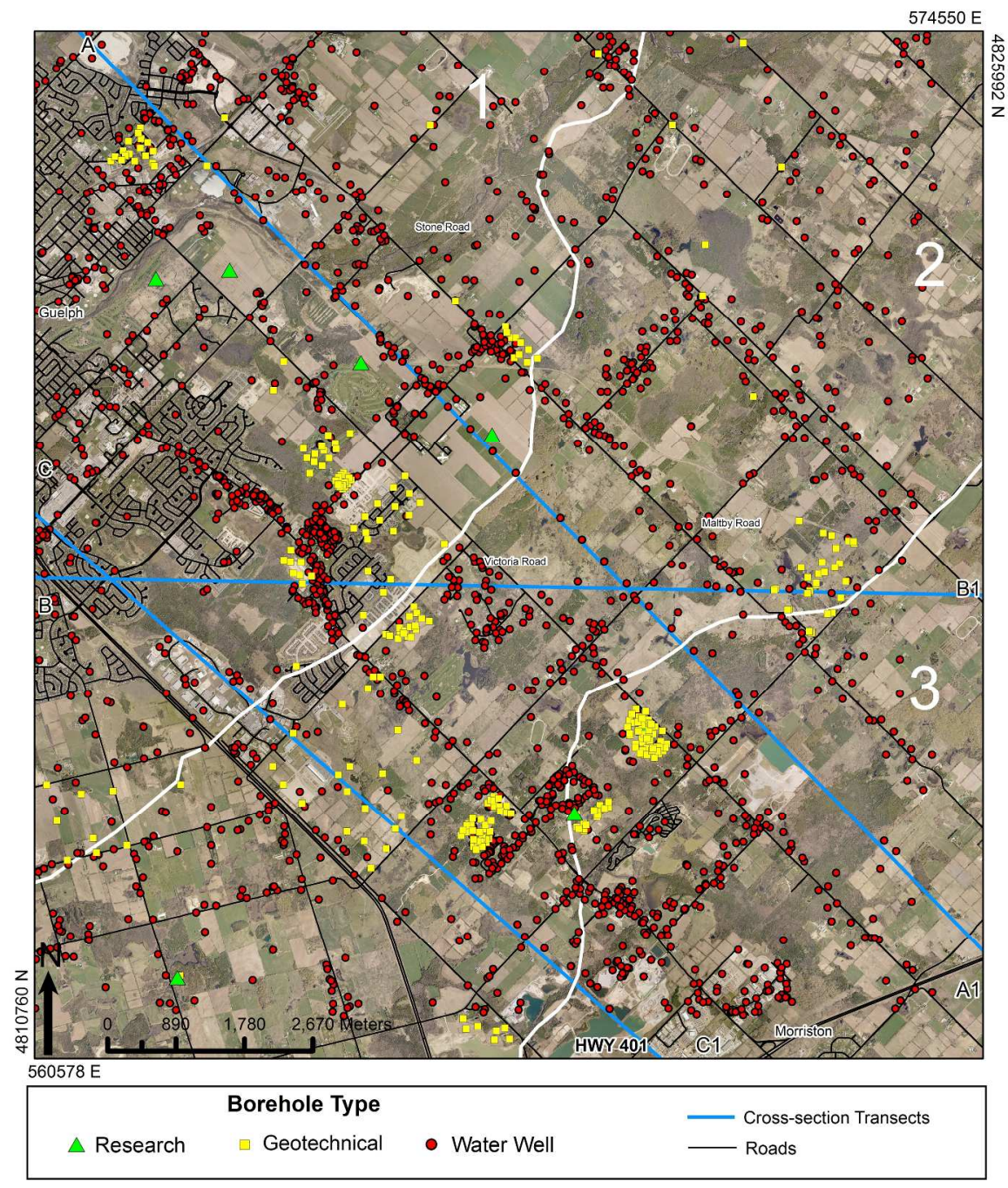

Map of the Regional Model Domain, data point locations and locations of cross sections (A-A1, B-B1, and C-

C1). There are 1245 lower quality data points (red dots) from the water well database, 263 moderate quality data points (yellow dots) from more reliable sources such as cored boreholes and geotechnical reports and 6 high quality data points (green dots) from related research of the co-authors. The three submodel regions are delineated with white lines and identified as Zone 1, Zone 2, and Zone 3 . Note that Zone 2 broadly coincides with the Paris Moraine. Coordinates are in UTM zone 17N, Datum: NAD83. 
Stratigraphy

$\square$ Outwash Deposit

Kame Deposit

Wentworth Till/Diamict

$\square$ Ablation Deposit

Port Stanley Till/Diamict

Undifferentiated Tills/Diamicts

Bedrock

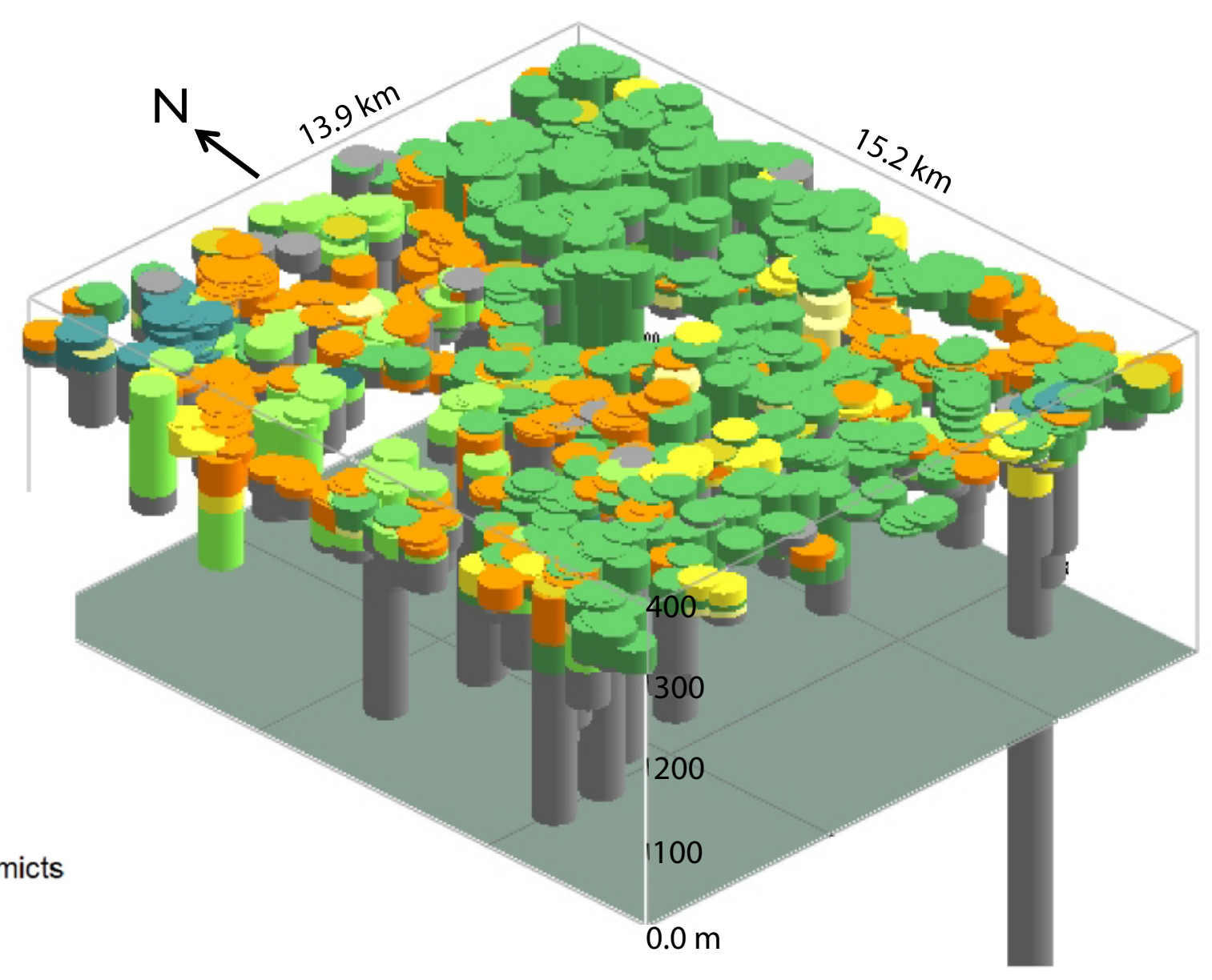

Figure 2, MacCormack et al., PDF 


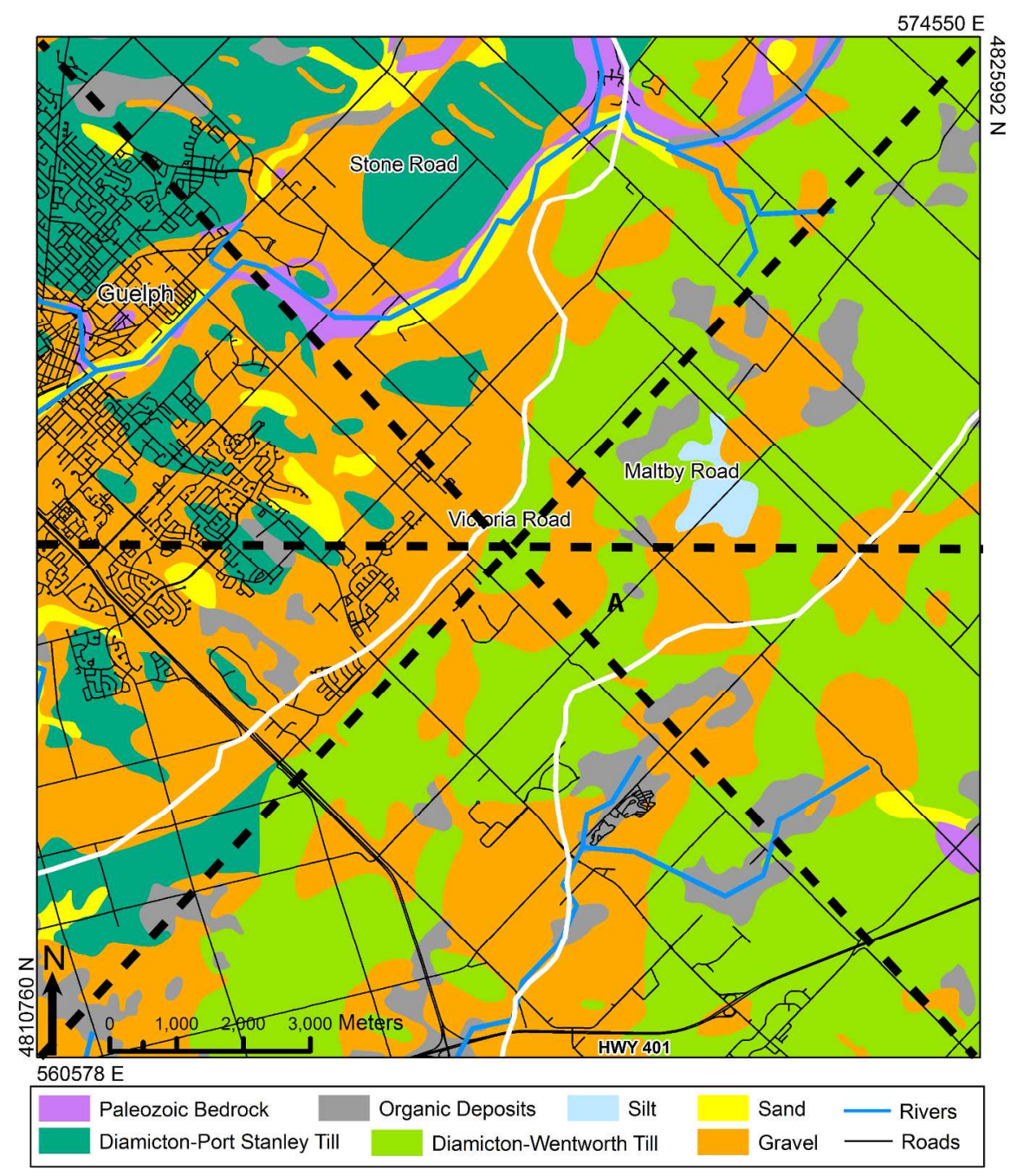

Three-dimensional geological models of A) the Original Regional Model for which all the data was interpolated, and B) the Subdivided Regional Model for which the 3 sub-models were interpolated independently and then recombined. Models have a vertical exaggeration of 10x. C) Surficial geology map of the study area for comparison with model outputs, note the improved correlation between the surficial geology map and the Subdivided Regional Model. Note that orange and yellow in A) and B) represent the sand and gravel (undifferentiated) of the outwash and kame stratigraphic units, whereas orange and yellow in C) represent gravel and sand respectively. Map in C) created using ESRI ArcMap 10.1 and data from Ontario Geological Survey (2003); white lines represent the sub-model boundaries defined in Figure 1; black hatched lines represent the location of the cross-sections in Figure 4. 
Single Variogram

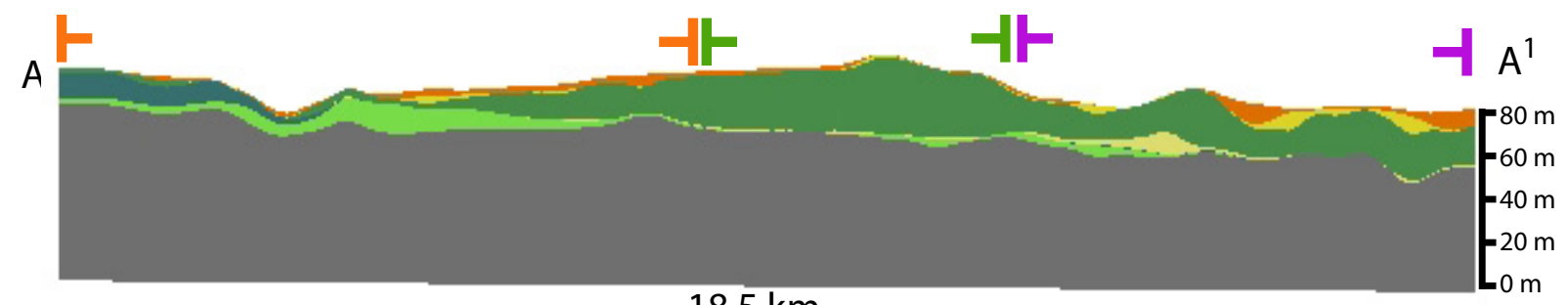

Multiple Variogram

$18.5 \mathrm{~km}$

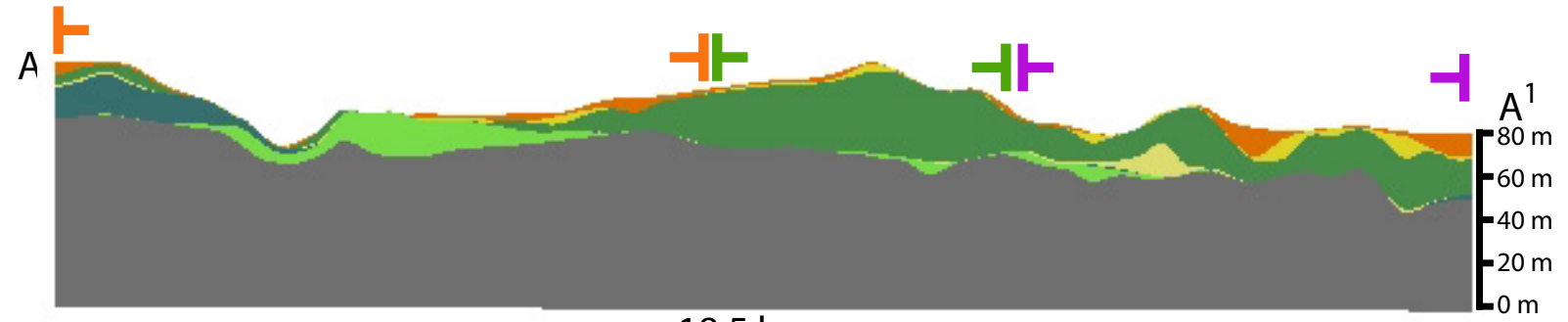

$18.5 \mathrm{~km}$

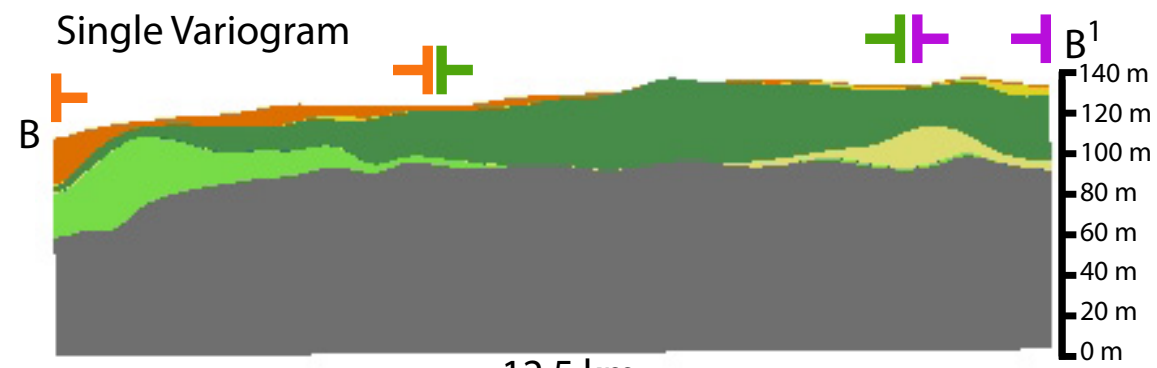

$12.5 \mathrm{~km}$

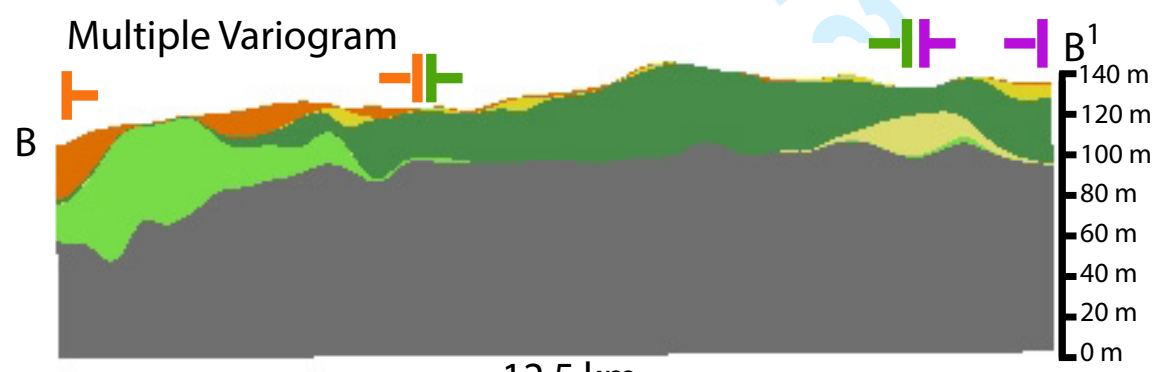

Stratigraphy

$\square$ Outwash Deposit

$\square$ Kame Deposit

$\square$ Wentworth Till

$12.5 \mathrm{~km}$

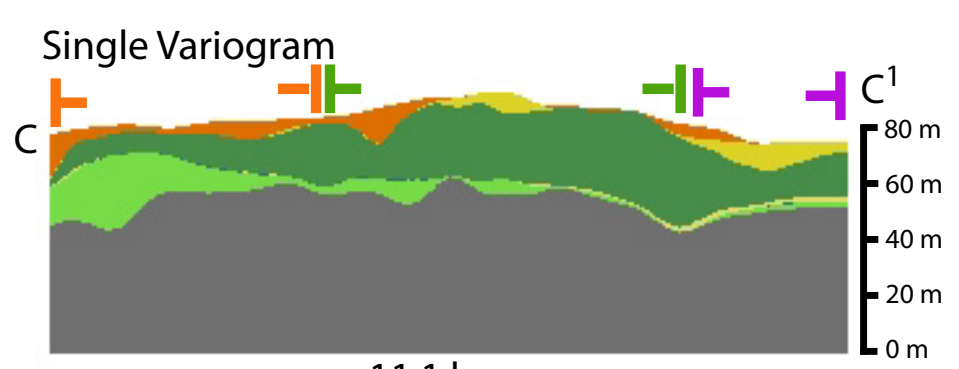

11.1 km

$\square$ Ablation Deposit

$\square$ Port Stanley Drift

$\square$ Undifferentiated Tills

$\square$ Bedrock

\section{Multiple Variogram}

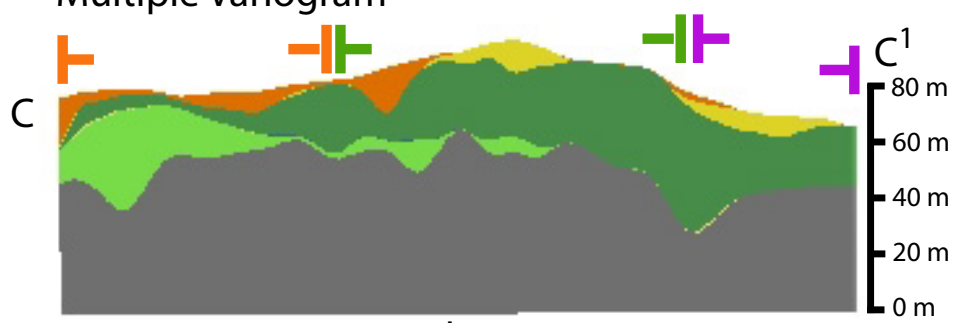

$11.1 \mathrm{~km}$

- Zone 1
-
- Zone 2
- Zone 3 

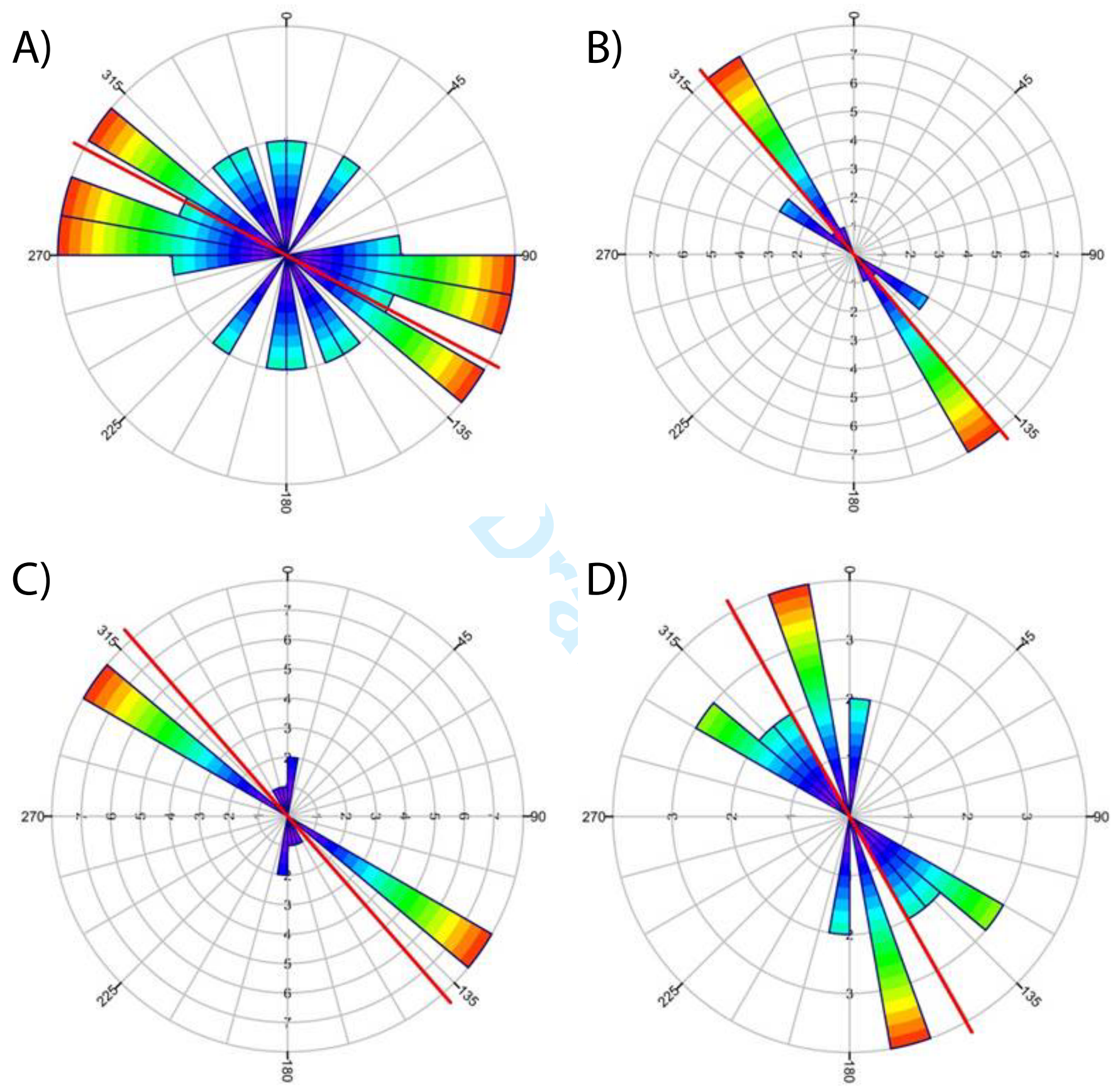

Figure 6, MacCormack et al., PDF 